\title{
The WTI/Brent oil futures price differential and the globalisation-regionalisation hypothesis
}

\author{
Michail Filippidis $^{1 *}$, George Filis ${ }^{2}$, Christos Floros ${ }^{3}$, Renatas Kizys ${ }^{1}$ \\ ${ }^{1}$ Department of Economics and Finance, Portsmouth Business School, University of \\ Portsmouth, Portsmouth, PO1 3DE, U.K. \\ ${ }^{2}$ Department of Accounting, Finance and Economics, Bournemouth University, Bournemouth \\ Business School, The Executive Business Centre, 89 Holdenhurst Road, BH8 8EB, \\ Bournemouth, U.K. \\ ${ }^{3}$ Department of Accounting \& Finance, School of Management and Economics, \\ Technological Educational Institute of Crete, 71004 Heraklion, Crete, Greece.
}

*Corresponding author: E-mail address: michail.filippidis@ @ort.ac.uk

\begin{abstract}
This study examines the globalisation-regionalisation hypothesis in the WTI/Brent crude oil futures price differential by considering a set of the potential determinants at 1,3 and 6 months to maturity contracts. To this end, we employ monthly data over the period 1993:12016:12 for a set of crude oil-market specific (convenience yield, consumption, production) and oil-futures market specific (open interest, trading volume) determinants. Our results can be outlined as follows. First, the WTI/Brent convenience yield spread can drive a wedge between the WTI and Brent oil futures prices for the nearby month and 3-month contracts. Second, the WTI/Brent oil production spread is a significant determinant for the 1-month, the 3-month and the 6-month to maturity contracts, while the WTI/Brent oil consumption spread is significant for the 6-month contract. Third, the WTI/Brent open interest spread appears to influence the oil futures price variability between the WTI and Brent for the 3-month and the 6-month contracts, while the WTI/Brent trading volume spread lends predictive power for the 1-month and the 3-month contracts. Fourth, the oil futures market does not appear to be globalised in every time period. We provide evidence of a regionalised oil futures market in the short-run horizon. Fifth, our robustness analysis lends support to the above findings. The findings of this study provide valuable information to energy investors, traders and hedgers.
\end{abstract}

JEL classification: C22, C51, G13, G15, Q40

Keywords: Brent, convenience yield, globalisation-regionalisation hypothesis, oil futures differential, WTI. 


\section{Introduction}

Crude oil is an important commodity and constitutes a large part of trade in global financial markets (Westgaard et al., 2011). In addition to this, the price of crude oil is an important factor which affects the global economy and contributes to financial stability (Chang, 2012). Since oil is traded through futures contracts, oil futures markets can play an important role in providing an efficient price discovery mechanism (Bekiros and Diks, 2008). Therefore, the analysis of crude oil futures contracts is an important tool to explain developments in the international crude oil market (Alquist and Arbatli, 2010). Furthermore, oil futures contracts are important derivative instruments for hedging the risk of unanticipated changes in future oil prices (Lean et al., 2010) and thus, traders and investors design hedging strategies using these contracts to deal with energy risk management.

Hedging strategies may vary across different crude oil benchmarks, such as WTI (West Texas Intermediate) and Brent. Hence, the degree of co-movement between those benchmarks provides valuable information regarding the effectiveness of crude oil benchmarks as hedging instruments (Reboredo, 2011). In this regard, Adelman (1984) posits that the world oil market is "one great pool", thus advancing the so-called globalisation hypothesis. Under a globalised market, the crude oil prices will move together in both upswings and downswings of the oil market. By contrast, the regionalisation hypothesis implies that crude oil prices do not move in unison. Therefore, the globalisation-regionalisation hypothesis recognises the existence of two states of the world oil market.

Historically, WTI trades slightly above Brent. This price advantage for WTI can be due to higher quality characteristics. Since WTI and Brent are generally considered as crude oils of similar quality, the consensus is that their prices should move in unison. However, factors such as regional logistical bottlenecks and geopolitical turmoil may have contributed to a significant divergence between WTI and Brent prices in late-2010, turning the price of WTI over Brent into a discount ${ }^{1}$. This is broadly indicative of regionalisation in crude oil market as far as the two major benchmarks are significantly affected by local market conditions and geopolitical events.

Turning to the infrastructure logistics, WTI as a landlocked crude oil can experience bottlenecks in supply via pipelines, whereas Brent does not experience bottlenecks, as it is

\footnotetext{
${ }^{1}$ In summary, the main causes for the observed variation over time in the oil price differential were (i) the increasing US domestic production from Shale formations (Bakken in North Dakota and Eagle Ford in Texas) and crude oil imports from Canada, as well as, (ii) the political instability in the Middle East, known as the Arab Spring. Reports and additional information can be found in Energy Information Administration (EIA) website.
} 
extracted at sea and transferred by ship. With reference to the geopolitical turmoil, Brent crude oil is affected mainly by geopolitical events such as political instability in Syria and Libya, pushing Brent to a higher price level ${ }^{2}$. This can be attributed to the fact that African and Middle Eastern oil production tends to be priced relative to the price of Brent. The extent to which regional oil market fundamental (supply and demand) conditions or world turmoil (the global financial crisis of 2007-2009) conditions as well as political tensions and instability appear to affect in a greater magnitude separately on one market relative to the other can be considered as a key supportive factor of decreasing levels of market integration and consequently amplifies regionalisation.

The WTI/Brent oil futures price differential (henceforth "oil futures differential") represents the futures price differential between the two crude oil benchmarks (WTI futures price minus Brent futures price). We examine the WTI (US) and Brent (European) crude oil markets rather than Dubai/Oman (Persian Gulf) crude oil market since both WTI and Brent have the most actively and highly liquid traded oil futures contracts globally (see, Elder et al., 2014). Our preference for the oil futures differential, as opposed to the oil spot differential, is motivated by relatively more accurate information contained in futures prices (see, Kao and Wan, 2012). Oil futures markets impart information that is used by traders to form expectations about future supply, demand and the equilibrium price of oil.

The behaviour of the oil futures differential is considered as a key element in explaining changes in oil market dynamics and international oil-trade flows ${ }^{3}$. The examination of the oil futures differential is essential, as the oil futures market's participants need to be aware of these changes in order to design effective hedging strategies and exploit arbitrage profit opportunities. Trading oil futures contracts in the oil futures market allows for hedging activities by commercial consumers and producers and arbitrage activities by market agents ${ }^{4}$. Given that historically the oil futures differential exhibits a mean reverting behaviour by

\footnotetext{
${ }^{2}$ Choi and Hammoudeh (2010) underscore the importance of geopolitical crises on the price of Brent which can adversely affect exports of crude oil from the Middle East and Africa. Barsky and Kilian (2004) emphasise the effect of events such as war in the Middle East on the oil markets.

${ }^{3}$ Energy Information Administration provides a detailed scope regarding the two crude oil futures benchmarks of WTI and Brent. For more information, see: https://www.eia.gov/todayinenergy/detail.php?id=24692

${ }^{4}$ Arbitrage is the process where agents taking advantage of a price differential between two commodities (WTI and Brent) by simultaneously buying and selling the two crudes to make profits. Hedging allows traders to protect (hedge) themselves against price risk by taking a position in the futures market which is opposite to their position in the physical market. Thus, hedging with oil futures contracts reduces the risk of price fluctuations on the physical market. When WTI and Brent crude oil trade closely together and hence move in unison, the scope for arbitrage opportunities diminish and the effectiveness of hedging strategies increases. On the other hand, if one market trades significantly above or below relative to the other, driving the oil market to operate at higher levels of price uncertainty, the arbitrageurs can take advantage of the oil futures differential and the effectiveness of hedging strategies declines.
} 
oscillating within fixed bounds apart from the post-2010 period, trading strategies with a particular emphasis to the oil futures differential can be employed to deal with energy risk management.

Surprisingly, the globalisation-regionalisation hypothesis has received limited attention in the use of oil futures prices (see, for instance, Milonas and Henker, 2001) and the research into determinants of oil futures differential is very limited (see, for example, Büyükşahin et al., 2013). Our choice to focus on the spread form in the set of explanatory variables which has not been discussed previously in other literature such as the WTI/Brent convenience yield spread, is justified by the fact that the oil futures differential is traditionally identified by the difference between the quality and freight rates (location) in the two crude oil markets. As a result, we should expect that additional differentials may possibly provide predictive power in market expectations regarding the future value in WTI and Brent benchmarks. Thus, this research aims to fill this void.

The contributions of the study can be described succinctly as follows. First, we consider a comprehensive set of crude oil-market specific factors and oil-futures market specific indicators, which have not been explored by the existing literature, to test the globalisationregionalisation hypothesis. Second, we focus on the futures oil price differentials rather than the spot oil price differentials, given that futures prices are more informative. Third, we take into account the recent period which has seen a significant divergence in the oil futures differential since late-2010. Finally, we consider these effects on various futures contracts maturities (i.e. 1, 3 and 6-month contracts).

Our findings are as follows. First, the WTI/Brent convenience yield spread has a negative and significant effect on the oil futures differential for the contracts near to maturity (1-month and 3-month). Second, the WTI/Brent oil consumption spread has a negative and significant effect on the oil futures differential for the 6-month to maturity contract. Third, the WTI/Brent oil production spread has a negative and significant effect on the oil futures differential among the corresponding maturities of 1-month, 3-month and 6-month contracts. Fourth, the WTI/Brent open interest spread has a negative and significant effect on the oil futures differential for the 3-month and the 6-month to maturity contracts. Fifth, the WTI/Brent trading volume spread has a positive and significant effect on the oil futures differential for the contracts near to maturity (1-month and 3-month). Overall, we suggest that the state of the oil futures market is not stable in every time period. Specifically, we provide evidence that the market is regionalised in the short-run and globalised in the longrun. 
The remainder of the paper is organised as follows: Section 2 reviews the literature of the study. Section 3 describes the data and provides a preliminary analysis of the variables. Section 4 outlines the econometric models. Section 5 analyses the estimation results. Section 6 offers some concluding remarks and discusses points for further research.

\section{Review of the related literature}

Chang et al. (2010) argue that among the four international crude oil benchmarks namely, WTI, Brent, Tapis and Dubai/Oman, only WTI and Brent are the world references for crude oil. WTI and Brent have similar qualities as both belong to the light sweet category ${ }^{5}$. As previously stated, our choice to examine the WTI and Brent markets is further justified by the fact that both markets have the most actively traded oil futures contracts in the world ${ }^{6}$. WTI is the reference not only for other types of crude oil produced domestically in the US, but also for imported crude oil produced in Canada. Therefore, WTI is the dominant crude oil benchmark in the large North American market.

Although Brent accounts for 1 percent of total crude oil production, it is used to set prices for crude oil produced and traded not only in the smaller European market but also in other parts of the world like the North Africa, the Middle East, the Australia and a number of countries in Asia ${ }^{7}$. Therefore, Brent represents two-thirds of the crude oil traded internationally (see Arouri et al., 2011; Filis et al., 2011). The WTI has the most liquid futures contract in the crude oil market compared with Brent. However, the trading volume of Brent futures contract exceeded the trading volume of WTI futures contract in April 2012 for the first time. This is indicative of the increasing significance of Brent as a global crude oil benchmark ${ }^{8}$.

While the Brent is considered as a global crude oil benchmark, the discussion as to whether this crude oil benchmark can be mimicked by the WTI is dominated by the so-called globalisation-regionalisation hypothesis, pioneered by Adelman (1984). As aforementioned,

\footnotetext{
${ }^{5}$ These quality differences are due to the higher percentage of gasoline and the lower percentage of heating oil in WTI than in Brent (Milonas and Henker, 2001). They are light because of low density and sweet because of low sulphur. Using light sweet crude oil, products like gasoline can be easily and cheaply produced. More specifically, WTI has an API (American Petroleum Institute) gravity of 39.6 degrees and contains 0.20 percent of sulphur, whereas Brent API gravity is 38.3 degrees and contains 0.40 percent of sulphur. Thus, a price advantage for WTI may arise due to being lighter and sweeter than Brent.

The interested reader can find all the necessary information about crude oils different quality characteristics in the following link: http://www.eia.gov/tools/glossary/index.cfm?id=A\#API_grav

${ }^{6}$ Although the Dubai/Oman futures contract is listed on the Dubai Mercantile Exchange Limited (DME), its trading volume is relatively small compared to the WTI and Brent which are considered as the most liquid traded futures contracts in the global oil market.

7 The source of the information can be found on the Energy Information Administration website: http://www.eia.gov/todayinenergy/detail.cfm?id=18571.

${ }^{8}$ Reports and additional information can be found in Energy Information Administration website.
} 
there is a globalised market when crude oil prices move in unison and a regionalised market when crude oil prices move with different intensities. Some studies related to the aforementioned hypothesis include the papers by Liu et al. (2015), Ji and Fan (2015), Wilmot (2013), Candelon et al. (2013), Reboredo (2011), Fattouh (2010), Hammoudeh et al. (2008), Kleit (2001), Milonas and Henker (2001), Gülen (1997, 1999) and Weiner (1991).

Evidence of regionalisation is endorsed by Weiner (1991) who argues that the ensuing effectiveness of energy policies, such as changes in the Strategic Petroleum Reserves in the US, depends on whether such policies pertain to the US market or are internationally transmitted. On the contrary, Gülen $(1997,1999)$ provides evidence that oil prices in different markets move closely together which is indicative of co-integration. In addition, Milonas and Henker (2001) indicate that oil prices are not fully integrated, with reference to the oil futures markets of WTI and Brent. Along a similar vein, Fattouh (2010) suggests that oil markets are not necessarily integrated in every time period and provides evidence of threshold effects in the adjustment process of crude oil price differentials to the long-run equilibrium.

Recently, Reboredo (2011) tests the globalisation-regionalisation hypothesis and finds evidence of globalisation during the period of 1997 to mid-2010. However, the globalisation hypothesis has been undermined by increasing regionalisation in the crude oil market since late-20109 . More recently, Liu et al. (2015) use high-frequency data to investigate the price discovery between WTI and Brent futures prices over the period of 2008-2011 and show evidence that oil supply disruptions at Cushing, the delivery point for WTI have significantly contributed to decreasing levels of co-integration between the WTI and Brent markets.

The recent developments are discordant with the notion of globalised markets, according to which crude oil of similar quality characteristics in different markets should be priced very closely to each other, resulting in a constant range of fluctuations in their price differential (Wilmot, 2013; Fattouh, 2010). Specifically, in our empirical analysis we seek to identify channels through which the oil market is globalised or regionalised, which in turn can trigger

\footnotetext{
${ }^{9}$ In late-2010, the combination of two key events in the US oil market; namely, an increasing volume of domestic production from North Dakota and Texas, as well as growing imports from Canada outpaced the Cushing's capacity to store and distribute the excess oil supply. The existing pipeline infrastructure in Cushing was inadequate to transport growing oil production to refineries in the Gulf coast. This created stockpile's bottlenecks in Cushing, turning the price of WTI over Brent into a discount. However, in early 2013, improvements in oil transportation infrastructure diminished the scope for further bottlenecks between Cushing and Gulf coast, putting upward pressure on WTI prices. Articles and reports on this subject may be found at Energy Information Administration for further reading around the price differences in WTI/Brent spread since late-2010. For more information, see: http://www.eia.gov/todayinenergy/detail.cfm?id=11891, http://www.eia.gov/forecasts/steo/special/pdf/2012_sp_02.pdf http://www.eia.gov/todayinenergy/detail.cfm?id=12391
} 
a range of responses in energy policy. Following Fattouh (2010), WTI and Brent, due to the similar quality and the most liquid traded futures contracts, are characterised by the absence of threshold effects in their price differential. Thus, the WTI/Brent oil futures differential is expected to be stationary within certain bounds. Through the mechanism of error correction, as indicated by the arbitrage activity, the oil futures differential adjusts to the certain boundaries in case of a deviation from the long-run equilibrium. Specifically, large deviations above or below a certain threshold can be eliminated quickly through arbitrage by the market participants in both futures markets, leading to a long-run equilibrium.

Against this background, our expectation is that the oil futures market is globalised in the long-run. However, the recent developments in crude oil market since late-2010, driven by regional supply and demand imbalances, and geopolitical unrest, which caused the Brent trading at a persistent premium over WTI, can be a hindrance to the adjustment process to the long-run equilibrium. Thus, while the oil futures market may be globalised in the long-run, this study seeks to advance the understanding of the short-run determinants of the oil futures differential, and hence regionalisation.

Within the limited body of research on the subject (see, among others, Hammoudeh et al., 2010; Caumon and Bower, 2004; Milonas and Henker, 2001), the importance of the fundamental factors (e.g., supply and demand) on the oil futures differential is accentuated. Specifically, Milonas and Henker (2001) underscore the importance of supply and demand conditions on oil futures differential. Similarly, research of Caumon and Bower (2004) suggest that the oil futures differential can be affected by different supply and demand events which occur in both markets. A similar picture is painted by Hammoudeh et al. (2010). They indicate that the oil futures differential is affected by fundamental and transitory components in both the WTI and Brent crude oil benchmarks.

Recently, Büyükşahin et al. (2013) identify that physical market fundamentals, such as the North American oil production (including the oil supply in US and imports from Canada), can help to explain the oil futures differential. Thus, supply and demand imbalances for WTI and Brent crude oil generate a significant short-term impact on their futures prices. For example, an unexpected increase in global demand for crude oil (triggered by the industrialisation of some emerging economies) or unexpected oil supply disruptions (due to pipeline limitations or political instability in the Middle East, for instance) can create supply and demand imbalances, which in turn, affect the WTI and Brent crude oil futures prices and thus, their oil futures differential. 
Our research is conceptually similar to Duan and Lin (2010), who ascribe the WTI/Brent spot price differential to crude oil convenience yields. In addition, futures prices incorporate the investor's belief regarding the value of the convenience yield (Mellios and Six, 2011). Convenience yield reflects market's expectations about the future availability of crude oil. It is highly associated with shortages and inventories of oil. According to Hull (2012), shortages in the crude oil market are reflected in a higher value of convenience yield. If the probability of shortages in the near future is perceived to be relatively low, and the holders possess relatively high inventories, convenience yield decreases. In the case of low inventories, convenience yield tends to be higher as shortages are more likely to occur.

Studies related to the determinants of the oil futures differential include the papers by Heidorn et al. (2015), Büyükşahin et al. (2013) and Milonas and Henker (2001). Specifically, Milonas and Henker (2001) who use various regression models to examine the relation among the WTI/Brent oil futures differential, convenience yield, supply and demand for both WTI and Brent crude oil. Fundamental factors of quality discrepancies are identified as the main drivers of the differential for those contracts away from expiration, whereas for contracts near to maturity, the main determinant is the convenience yield. More recently, Büyükşahin et al. (2013) employ an autoregressive distributed lag (ARDL) model on daily data to examine fundamental and financial drivers of the nearby oil futures differential between WTI and Brent. They conclude that positions from commodity index traders and physical traders in both futures markets partly help to predict the behaviour of the oil futures differential.

Furthermore, Heidorn et al. (2015) use a term structure model on weekly data to investigate the impact of fundamental and financial traders' market position on the Brent/WTI oil futures differential for a range of different maturities. They find that financial rather than fundamental traders tend to exercise a significant influence on WTI/ Brent market integration by eliminating price differences between them. As aforementioned, the goal of this paper is to investigate the globalisation-regionalisation hypothesis in the WTI/Brent oil futures price differential by assessing a broader set of crude oil-market specific factors and oil-futures market specific indicators. There is little research attempts in the above context and thus we seek to contribute to this scarce literature.

\section{Data and preliminary analysis}

The sample period runs from January 1993 to December 2016, including 288 monthly observations. The time period is dictated by data availability. 


\subsection{WTI/Brent oil futures differential}

The present study focuses on the oil futures contracts that are traded in two international markets. For the US crude oil market, we include 1, 3 and 6 expiration month futures contracts available from the New York Mercantile Exchange (NYMEX). For the European crude oil market, we include the Intercontinental Exchange (ICE) oil futures contracts for the same expiration months. Prices of crude oil are expressed in US dollars per barrel and the size of a contract is 1,000 barrels (contract unit) with a minimum fluctuation of $\$ 0.01$ per barrel. These prices are extracted from Bloomberg.

The identification of potential determinants on the oil futures differential is examined for 1,3 and 6-month maturities of futures contracts. First, the 1-month futures contract has the greatest amount of predictive information which can be gathered to explain future movements and volatility in the spot price (see Hammoudeh et al., 2003). Second, futures contracts with shorter maturities (1-month and 3-month) present higher trading volume and thus generate greater liquidity (see Hammoudeh and Li, 2005; Hammoudeh and Yuan, 2008) than futures contracts for other maturities. Third, the 6-month oil futures contract is the average contract where the price of risk for the far to maturity month does not exceed the premium received on the nearest to maturity month. According to Miffre (2004), hedging with longer maturity futures contracts (six to nine months) is more uncertain than hedging with shorter maturity futures contracts (three to six months). In addition, Graham-Higgs et al. (1999) find that the futures market is efficient for maturities shorter than 6 months. Therefore, the prices of such contracts reflect all available information.

Monthly futures prices and the oil futures differential (both at 1, 3 and 6 months to maturity) are displayed in Figures 1 and 2.

\section{[PLEASE INSERT FIGURES 1 AND 2 HERE]}

It is clear that both markets were traded at similar prices with the WTI price having a small premium over Brent. Since late-2010, this relationship began to change to a significant divergence between WTI and Brent prices, turning the price of WTI over Brent into a discount. However, inside the period 2011-2015 the substantial premium of Brent over WTI diminished gradually to a small premium and returned to prior to late-2010 levels in December 2015, which coincided with the lifting of the US crude oil export ban. As a result, in the early 2016, the oil futures differential narrowed and almost returned to parity. By the end of December 2016 the oil futures differential widened slightly again (a higher rise in Brent opposite to WTI). 
Figures 1 and 2 further show that the WTI and Brent oil futures prices move closely together during the period 1993-2010 (apart from the late-2010), which suggests the existence of a globalised market in the long-run. On the other hand, during the period 2011-2016 (apart from December 2015), WTI was trading at a persistent discount vis-à-vis Brent. This discount was pronounced from 2011 to 2014, when the difference between the WTI and Brent widened considerably. This result suggests that at times of intense regional logistical bottlenecks and severe geopolitical unrest which clearly emerged during 2011-2014, the globalised nature of the oil futures market appears to be challenged.

\subsection{Explanatory variables}

In this paper, we use the spread of the WTI/Brent convenience yield, WTI/Brent oil consumption, WTI/Brent oil production, WTI/Brent open interest and WTI/Brent trading volume as possible explanatory variables. The Energy Information Administration (EIA) database is the source of monthly historical data for oil-specific explanatory factors such as, crude oil production ${ }^{10}$ and petroleum consumption ${ }^{11}$. It is worth noting that our measure of the WTI crude oil production might in part reflect the rapid growth in US shale oil production (shale oil revolution) which was triggered by technological advances in drilling, and contributed to the recent developments in US crude oil production. In particular, shale oil production experienced an increase in 2003 and a rapid expansion in 2009, which in turn led almost a half of US crude oil production to result from the accumulation of US shale oil production in 2014 (see, for instance, Kilian, 2016). The open interest and the trading volume represent trading activity in the oil futures market ${ }^{12}$. Open interest and trading volume together are employed to indicate changes in market depth and provide information in explaining futures price volatility. Market participants use these variables as indicators of price trends in the futures markets. We use the open interest and the trading volume of WTI

\footnotetext{
${ }^{10}$ Although WTI is produced only in the Midwest region, it is considered as the major benchmark in the US (Speight, 2011). Crude oil production in the US and crude oil imports from Canada into PADD 2 region is used as a proxy for WTI oil production, whereas the Brent crude oil output is given by the sum of the UK and Norway total crude oil production in the North Sea (Hamilton, 2008) insofar as both countries hold the majority of oil fields in this area.

${ }^{11}$ EIA uses product supplied as a proxy for US petroleum consumption. We employ this variable as a proxy for WTI oil consumption. In the US, oil consumption is benchmarked to the domestically produced WTI (Hammoudeh et al., 2010), whereas our measure of Brent oil consumption is constructed using data on petroleum consumption in France, Germany, Italy and the UK. This is due to the fact that Brent is typically refined in Europe and is consumed in large quantities in the Northwest Europe (Speight, 2011). Candelon et al. (2013), argue that due to the continuous decline in production, Brent crude oil has largely consumed locally in Europe.

${ }^{12}$ Open interest is the number of outstanding contracts that have not been delivered on a specific day. Trading volume is the number of contracts bought and sold for a given time period.
} 
and Brent at 1, 3 and 6 expiration month futures price contracts. Data on the open interest and the trading volume are collected from Bloomberg.

Furthermore, we use the ICE LIBOR ${ }^{13}$ (Intercontinental Exchange, London Interbank Offered Rate) and the US Treasury bill rate, both at 1, 3 and 6 months as risk-free interest rates to construct our measure of convenience yield. Specifically, we employ the LIBOR (Knetsch, 2007) as the main risk-free interest rate, whereas the US Treasury bill rate (Gospodinov and Ng, 2013; Milonas and Henker, 2001), is used as an alternative measure of a risk-free interest rate in order to test the robustness of our results. Both rates are known as the world's most widely-used benchmarks for risk-free interest rates. Data on the ICE LIBOR interest rate are extracted from Bloomberg, whereas data on the US Treasury bill rate are collected from Datastream ${ }^{\circledR}$. In addition, for the construction of the convenience yield we use WTI and Brent spot crude oil prices, which are obtained from EIA.

It is worth noting that the choice of the US Treasury bill rate as an alternative measure is based on the recent claims of extensive manipulation of the LIBOR which contributed to increasing concerns about the integrity of this rate, with a particular emphasis on the financial crisis of 2007-2009. From a theoretical perspective, banks could gain cumulative returns by manipulating LIBOR (if they indicate a less volatile rate so that to attract the attention of investors). As far as payments in loans by companies are based on LIBOR movements, it appears to have an impact on their borrowing costs and further reduces the reliability of the banking sector and the confidence in the financial markets. According to Duffie and Stein (2015), manipulating the LIBOR is beneficial in periods of financial stress, since a lower interest rate implies that a bank is able to receive credit and in case of some small distortions in LIBOR fixing, as long as a bank's trading positions in a derivative market are large enough and indexed to LIBOR. The next section presents in detail the construction of the spread variables.

\subsection{Formulation variables}

The oil futures differential is given by:

$S F P_{t, n}=F W_{t, n}-F B_{t, n}$

where $S F P_{t, n}$ is the difference (spread) between WTI and Brent crude oil futures prices at time $t$ and maturity $n, F W_{t, n}$ is the futures price for WTI at time $t$ and maturity $n$ and $F B_{t, n}$ is the futures price for Brent at time $t$ and maturity $n$.

Similarly, the convenience yield spread $(S C Y)$ is given as follows:

\footnotetext{
${ }^{13}$ Due to the fact that government bonds include liquidity premia, Alquist et al. (2014) argue that LIBOR seems to provide a good measurement of the borrowing costs experienced by companies in oil industry.
} 
$S C Y_{t, n}=C Y W_{t, n}-C Y B_{t, n}$

where $C Y W_{t, n}$ and $C Y B_{t, n}$ are the WTI and Brent convenience yields at time $t$ and maturity $n$. To calculate the convenience yield $(C Y)$ in crude oil markets we adopt the recent approach proposed by Gospodinov and $\mathrm{Ng}$ (2013). This approach consists of calculating the net (of storage and insurance costs) ${ }^{14}$ percentage convenience yield as follows:

$C Y_{t, n}=\frac{\left(1+\mathrm{i}_{\mathrm{t}, \mathrm{n}}\right) \mathrm{S}_{\mathrm{t}}-\mathrm{F}_{\mathrm{t}, \mathrm{n}}}{\mathrm{S}_{\mathrm{t}}}$

where $i_{t, n}$ is the risk-free interest rate at time $t$ and maturity $n, S_{t}$ denotes the spot price of crude oil for delivery at time $t$, and $F_{t, n}$ denotes the futures price of crude oil for delivery at time $t$ and maturity $n$.

It is worth mentioning that the convenience yield can be associated with shifts in precautionary oil demand arising from an unexpected disruption in oil supply or an unexpected growth in oil demand (see, for example, Kilian and Park, 2009). In other words, shifts in precautionary demand may represent increasing uncertainty in the oil market. In this regard, the greater the uncertainty in the oil market, the higher the convenience yield. Furthermore, uncertainty about oil supply shortfalls could potentially be attributed to geopolitical unrest caused by political instability and wars in the Middle East such as those in the Persian Gulf crisis of 1990-1991, the second Iraq war of 2003 and the Arab Spring of 2011 (see Alquist and Kilian, 2010; Kilian, 2009). Therefore, we suggest that the geopolitical turmoil is well captured by the convenience yield that we employ in this study.

Further, the oil consumption spread $(S C O)$, the oil production spread $(S P R)$, the open interest spread $(S O I)$ and the trading volume spread (STV) are given as follows:

$S C O_{t}=C O W_{t}-C_{C O B}$

$S P R_{t}=P R W_{t}-P R B_{t}$

$S O I_{t, n}=O I W_{t, n}-O I B_{t, n}$

$S T V_{t, n}=T V W_{t, n}-T V B_{t, n}$

where $\operatorname{COW}_{t}\left(C O B_{t}\right)$ indicate the WTI (Brent) oil consumption, $P R W_{t}\left(P R B_{t}\right)$ represent the WTI (Brent) oil production and finally, $\operatorname{OIW}_{t, n}\left(T V W_{t, n}\right)$ and $O I B_{t, n}\left(T V B_{t, n}\right)$ are the WTI and Brent open interests (trading volumes) at time $t$ and maturity $n$, respectively. The next section reports the preliminary analysis.

3.4 Descriptive statistics of the variables under consideration

\footnotetext{
${ }^{14}$ Fama and French (1988) in their empirical analysis for the theory of storage assume that the relative warehouse costs of holding the commodity are roughly constant.
} 
All explanatory variables are expressed in logarithms, except for $S C Y$ whereas the variables measuring oil consumption and oil production are seasonally adjusted. Descriptive statistics are presented in Table 1. Panel A summarises descriptive statistics of the oil futures differential $(S F P)$, the convenience yield spread (SCY) both for 1, 3 and 6 months to maturity and the oil consumption spread $(S C O)$. Panel B summarises the open interest spread (SOI), the trading volume spread (STV) both for 1, 3 and 6 months to maturity and the oil production spread $(S P R)$.

In panels $\mathrm{A}$ and $\mathrm{B}$, we indicate that the $S F P$ is fairly volatile as the contract approaches maturity. Also, the $S C Y$ is more volatile for longer maturity futures contracts, exhibiting greater uncertainty of the future availability of oil in a more distant future, since the future path of oil prices is highly uncertain as we move further out into the future. The Jarque-Bera statistic rejects the null of normality in all of the series. The observed non-normality is also evident in the skewness and kurtosis statistics.

\section{[PLEASE INSERT TABLE 1 HERE]}

The Augmented Dickey-Fuller (ADF), (Dickey and Fuller, 1981) and Philips-Perron (PP), (Phillips and Perron, 1988) unit root tests are reported in Table 2 (see Panels A and B). Both tests indicate the presence of a unit root for the WTI and Brent futures prices, regardless the maturity of the futures contract. The ADF test decisively rejects the null of a unit root for the differential form of our explanatory variables with an exception of the SPR. Similarly, the PP test cannot reject the null hypothesis of a unit root for the SPR. Because these results of the unit root rests may be biased towards the presence of a unit root in the event of a structural break, we also run the Zivot-Andrews (ZA), (Zivot and Andrews, 1992) unit root test that allows for the presence of structural breaks in the constant, the trend or in both the constant and trend. The results of these tests are reported in Panel C. Crucially, the ZA test rejects decisively the unit root in the SFP. This result resonates well with evidence of co-integration between the two benchmarks, as the difference between the WTI and Brent oil prices can be perceived as a deviation from the long-run equilibrium relation (Fattouh, 2010; Chevillon and Rifflart, 2009).

The results of the ADF and PP tests for the rest of the variables are endorsed by the ZA test. Variables such as SFP, SCY, SOI, STV (for all different maturities), and SCO appear to be stationary in levels and thus the null hypothesis of unit root is rejected. Also, the tests show that $S P R$ features a unit root, if the ADF and PP tests are used. Although the ZA test rejects the null of a unit root (in terms of the constant), as the variable shows no evidence of structural break, we establish the stationarity of $S P R$ by transforming this variable into first 
differences. Furthermore, the ZA test is indicative of determining endogenously a structural break in the $S F P^{15}$. This vindicates the use of a dummy variable in the regression models in Section 4. More specifically, the structural break in the SFP is detected in January 2011, which is almost in line with Büyükşahin et al. (2013) who document a structural break in the middle of December 2010 by using a Chow test and roughly matches the period for which the dummy variable we construct takes on value 1 . Furthermore, a structural break in the $S F P$ is also evident in terms of a Bai and Perron (Bai and Perron, 1998) breakpoint test. Similarly, a structural change is detected endogenously in January $2011^{16}$.

\section{[PLEASE INSERT TABLE 2 HERE]}

Table 3 reports the coefficients of unconditional correlation of the series in order to identify the linear relation among the variables under investigation. Overall, the unconditional correlation between the dependent variable and the explanatory variables alters substantially. A negative and relatively weak or moderate correlation is observed between $S F P$ and $D S P R$, SFP and SCO, while a positive and relatively weak or moderate correlation is observed between SFP and the remaining explanatory variables (with the exception of the SCY for the 1-month).

\section{[PLEASE INSERT TABLE 3 HERE]}

Further to the above diagnostic tests, we employ a multiple linear regression to proceed to the stage of the empirical analysis and the discussion of results.

\section{Methodology}

This study builds upon a battery of single-equation multiple linear regression models. The dependent variable is the oil futures differential (SFP) between the WTI and Brent oil futures prices. We investigate the determinants of SFP by employing a set of explanatory variables, such as the convenience yield spread $(S C Y)$, the oil consumption spread (SCO), the oil production spread $(S P R)$, the open interest spread $(S O I)$, and the trading volume spread $(S T V)$. The following equation defines the general (i.e. least restrictive) model that is estimated by the ordinary least squares (OLS) method:

$$
\begin{aligned}
& S F P_{t}=\alpha_{0}+\alpha_{1} S F P_{t-1}+\alpha_{2} S C Y_{t}+\alpha_{3} S C O_{t}+\alpha_{4} S P R_{t}+\alpha_{5} S O I_{t}+\alpha_{6} S T V_{t}+ \\
& \alpha_{7} D_{t}+\varepsilon_{t} \text {, where } \varepsilon_{t} \sim \text { iid. } N\left(0, \sigma^{2}\right)
\end{aligned}
$$

In addition to the aforementioned determinants, we further include the first lag of the dependent variable to take into account serial correlation $\left(S F P_{t-1}\right)$. The inclusion of the

\footnotetext{
${ }^{15}$ Results are available from the authors upon request.

${ }^{16}$ Results are available from the authors upon request.
} 
lagged dependent variable captures dynamic effects in SFP behaviour, such as persistence, path dependencies and sluggish adjustment to a shock, and thus contributes to an improved performance of our model. We also employ a dummy variable in order to capture the structural change in the level of the oil futures differential in the post-2010 period. It takes the value 0 from January 1993 to July 2010 and the value 1 from August 2010 to December 2016. Finally, $\varepsilon_{t}$ is the random disturbance term, which is assumed to be independently and identically distributed with a normal distribution, with mean 0 and variance $\sigma^{2}$. In our regression models, firstly we examine individually the effects of each explanatory factor on the SFP. Secondly, we consider all explanatory variables collectively. This process is reiterated for maturities of 1,3 and 6 months.

Overall, we posit the following testable hypotheses:

Hypothesis 1: A positive change in the SCY leads to a decrease in the SFP.

Convenience yield represents the benefits from holding a physical asset (i.e. a barrel of oil). It reflects the market's expectations about the future availability of crude oil. Futures prices will go down when the benefits of holding the barrels of oil are high and vice versa. For example, the higher the level of inventories today, the lower the convenience yield and therefore the higher the energy trader's expectation of scarcity to occur in the near future in the oil markets, which tends to put an upward pressure on oil futures prices. We suggest that a positive change in the $S C Y$ (i.e. an increase in the WTI convenience yield or a decrease in the Brent convenience yield) lowers the WTI futures price relative to the Brent futures price, leading to an overall decrease in the SFP and hence, $\alpha_{2}<0$.

Hypothesis 2: A positive change in the SCO leads to an increase in the SFP.

Crude oil consumption approximates the demand for oil. An increase in oil demand is followed by increases in oil prices. The higher the intensity of energy consumption, the higher the impact on oil prices (Maghyereh, 2004). We indicate that a positive change in the SCO (i.e. an increase in WTI consumption or a decrease in Brent consumption) increases the WTI futures price relative to the Brent futures price, leading to an overall increase in the SFP and hence, $\alpha_{3}>0$.

Hypothesis 3: A positive change in the SPR leads to a decrease in the SFP.

Crude oil production approximates the supply of oil. Oil supply increases lead to reductions in oil prices. Moreover, fears for capacity constraints are expected to put an upward pressure on futures prices. We consider that a positive change in the SPR (i.e. and increase in WTI 
production or a decrease in Brent production) decreases the WTI futures price relative to the Brent futures price, leading to an overall decrease in the SFP and hence, $\alpha_{4}<0$.

Hypothesis 4: A positive change in the SOI affects the SFP.

We consider the open interest as a proxy for hedging demand in the oil futures market. According to Hong and Yogo (2012), open interest will have a positive (negative) effect on the futures price, if there is excess demand for hedging from oil consumers (producers) who wish to buy long (sell short) futures contracts in anticipation of higher economic activity. The sign of the open interest effect will depend on whether hedging consumers or hedging producers prevail in the market. We recommend that a positive change in the SOI, leading to an increase or a decrease in the SFP and hence, $\alpha_{5}>0$ or $\alpha_{5}<0$.

Hypothesis 5: A positive change in the STV leads to an increase in the SFP.

Trading volume approximates the flow of information arriving in the futures market. Following Chordia and Swaminathan (2000), high-volume assets respond faster to marketwide information than low-volume assets. Therefore, a change in the trading volume spread should have a significant effect on the relative futures market valuation of WTI versus Brent. A positive relation between the futures price differential and changes in the volume of trading is predicted by Jennings et al. (1981) who argue that short positions are possible, but are more costly than long positions. Therefore, an increase in the volume of trading is indicative of a bull market with long positions as opposed to a bear market with short sales. We propose that a positive change in the STV (i.e. an increase in the WTI trading volume or a decrease in the Brent trading volume) increases the WTI futures price relative to the Brent futures price, leading to an overall increase in the SFP and hence, $\alpha_{6}>0$.

Hypothesis 6: If the coefficients of the model $\alpha_{2}-\alpha_{6}$ are collectively significant (i.e., the corresponding determinants drive a significant wedge between WTI and Brent futures prices and therefore contribute to price disparities) then futures markets are said to be regionalised. WTI and Brent are the most extensively traded commodities futures contracts in the worldwide oil futures markets. Deviation from the parity between WTI and Brent triggered by our comprehensive set of determinants attests oil futures market regionalisation. We use a standard $\mathrm{F}$ test to determine whether the selected determinants are jointly significant. If the coefficients are not significantly different from zero, then the futures markets are said to be globalised.

\section{Empirical analysis}


Section 5.1 describes the estimation analysis based on the determinants of the oil futures differential. Section 5.2 summarises two robustness checks. For the first robustness check, we use the US Treasury bill rate as an alternative risk-free interest rate to compute the convenience yield. A data availability issue imposes a constraint on the sample period, as the 1-month US Treasury bill rate is only available from August 2001. Thus, we investigate the period from 2001:8 to 2016:12 (185 monthly observations). However, for the 3-month and the 6-month US Treasury bill rate, we consider the main sample period of 1993:1-2016:12. For the second robustness check, we employ a Seemingly Unrelated Regression (SUR) estimation approach (Zellner, 1962), in which we jointly estimate the oil futures differential for the 1-month, 3-month, and 6-month futures contracts. The SUR estimation approach conveniently takes into account the possible presence of correlations among the random disturbance terms from the three equations. Finally, in Section 5.3, the globalisationregionalisation hypothesis is tested.

\subsection{Determinants of the oil futures differential}

Tables 4-6 summarise the results for the oil futures differential for the 1-month, 3-month and 6-month futures contracts, respectively.

\section{[PLEASE INSERT TABLES 4-6 HERE]}

The lagged dependent variable and the dummy variable have a statistically significant effect in all specifications. The coefficient on the lagged dependent variable (dummy variable) has the expected positive (negative) sign. More specifically, the former indicates the degree of persistence in the oil futures differential, whereas the latter indicates the existence of a structural break. In specifications from 1 to 5 , predictors of the oil futures differential enter regressions individually, whereas specification 6 employs the entire set of predictors. Our analysis primarily focuses on specification 6 , since we seek to determine how additional predictors simultaneously affect the dependent variable, although we do refer to the remaining specifications when required.

The relation between the oil futures differential and the convenience yield spread is the first issue of interest. The convenience yield measures the increased gain that the trader receives from holding barrels of crude oil rather than holding futures contracts for crude oil. The results show that the convenience yield spread exerts a significant effect for the nearest to maturity month and the 3-month to maturity futures contracts, whereas the same does not hold true for the 6-month to expiration. Furthermore, consistently with Gospodinov and $\mathrm{Ng}$ (2013), the convenience yield spread has the expected negative sign. 
This finding can be explained as follows. The convenience yield is negatively related to the inventory level in the oil spot market (Fama and French, 1998). More specifically, a decrease in the inventory level today is associated with a higher convenience yield and an increase in the spot price of oil. A higher convenience yield net of storage cost implies that traders are more willing to hold physical assets and are less willing to buy futures contracts of crude oil. As a result, traders will benefit from increasing the demand for barrels of oil in the spot market (which contributes to increases in spot prices) and selling short oil futures contracts (which results in decreases in futures prices).

Next, we focus on the empirical relation between the oil futures differential and oil-specific fundamental variables. The results show that the coefficient of the oil production spread is consistent with the initial expectation of a negative sign and also significant for all corresponding maturities of 1-month, 3-month and 6-month contracts. Moreover, the oil consumption spread has a negative and significant effect on the oil futures differential for the 6-month contract, which disagrees with our initial expectation of a positive sign. The findings suggest weak evidence that the oil futures differential is influenced by the oil consumption spread and stronger evidence that the predictability of the oil futures differential can be ascribed to the oil production spread.

A plausible explanation for the negative and significant effect of oil consumption spread on the oil futures differential in the 6-month contract can be as follows. An increase in consumption today triggers an upward movement in oil spot prices. However, energy traders in futures markets would expect a commensurate increase in oil production in the future, which will subsequently drive spot oil prices at lower levels. Thus, even though today spot prices and possibly the shorter maturities of 1-month and 3-month futures prices may increase due to an increase in oil consumption, this effect is the reverse for the far maturity months. This framework can potentially explain the significant finding for the 6-month contract and more precisely the unexpected negative sign.

Turning our attention to the importance of the oil production spread on the oil futures differential, the effect is significant for all corresponding maturities. Hence, in light of the events which took place and caused changes in crude oil market, the analysis of the oil production effects is warranted. As aforementioned, the mismatch between US oil production and the existing infrastructure capacity that led to a disruption of oil supply provides a plausible explanation for the observed time-variation in the oil futures differential. Before this supply disruption, WTI traded at a small premium over Brent. The supply disruption in 
Cushing triggered WTI to trade lower than Brent. In addition, Brent oil production experienced a constant decline with no visible repercussion on the oil futures differential.

Our findings further indicate that the open interest spread exerts a negative and significant effect on the oil futures differential for the 3-month and 6-month contracts. As aforementioned, the open interest measures hedging demand activity in the futures markets (Hong and Yogo, 2012). This finding can be attributed to the excess hedging demand from the part of producers in anticipation of higher economic activity who sell short the contracts and drive an upward movement to the open interest and therefore there is a lower number of contracts for hedging. This reduces the futures price since there is a limited arbitrage by speculators.

Finally, the trading volume spread has a positive sign and appears as a statistically significant predictor of the oil futures differential for the 1-month and the 3-month contracts. We consider that the trading volume measures the trading activity which reflects all market relevant information and exerts a positive impact on futures price for maturities shorter than 6 months. A plausible explanation of this result is due to the fact that the contracts with shorter maturities such as the 1-month and the 3-month characterised by a greater amount of information, higher trading volume, greater liquidity and therefore a higher price movement. The nearby or front month contract is the most liquid contract. Furthermore, the 3-month oil futures contract of WTI traded on the NYMEX has the largest market share in the world (see Hammoudeh and Li, 2005).

Overall, the above findings show that the oil futures differential is driven by the convenience yield, the fundamental factors of supply and demand and the financial indicators of open interest and trading volume. Our results suggest that the convenience yield spread provides a strongly significant predictive power for the nearby month contract and a moderately significant predictive power for the 3-month to maturity contract. In this regard, our results are in accordance with those reported by Milonas and Henker (2001). Specifically, Milonas and Henker (2001) find that for futures contracts with longer maturity, the oil futures differential is less responsive to the convenience yield than for shorter maturity futures contracts.

With reference to the oil production spread our findings suggest that the oil futures differential is strongly (weakly) and significantly affected by the oil production spread for the 1-month (3-month, 6-month) contracts and therefore can be driven by supply imbalances. This is in agreement with the findings of Büyükşahin et al. (2013). They conclude that the North American oil supply variables trigger a statistically significant long-run relation 
between the WTI/Brent crude oil nearby futures prices spread and the physical market fundamental variables, with a particular emphasis on episode in which increasing supply of oil depressed the WTI oil futures price.

In addition, the oil consumption spread exhibits a significant and moderate effect on oil futures differential only for the 6-month futures contract. This evidence broadly shows the decreasing importance of the fundamental factor of demand as a driver of the oil futures differential. On general principles, the petroleum consumption accounts for a proportion of 36 percent of all the energy consumed in the US. However, petroleum consumption in North America and Europe shows a declining trend the last decade which can be attributed to the use of more environment-friendly resources and the recent economic recession of 2007$2009^{17}$. We suggest that the above discussion can be interpreted as a plausible explanation further to the aforementioned trading activity by energy traders regarding the relationship between the oil consumption spread and the oil futures differential.

Concerning the open interest spread and the trading volume spread, we are able to document the importance of the financial trading in the oil futures market by traders and investors who consider the oil futures differential as a financial asset. They invest in the oil futures market in order to hedge themselves or to make profits. Thus, we conclude that financial activity is important in explaining movements in the oil futures differential. Our results agree with Büyükşahin et al. (2013), who illustrate that the predictability of the WTI/Brent oil futures differential arises from both financial and physical traders' activity. In addition, our findings partly agree with Heidorn et al. (2015), who emphasise the relative importance of financial traders relative to fundamental traders in predicting the oil futures differential.

Finally, our results could support in some extent the importance of the US shale oil revolution and geopolitical turmoil to the oil futures differential. Although our empirical analysis does not explicitly focus on these two concepts and our attempt to capture their impact is not pronounced targeting both concepts, we are able to provide a plausible explanation regarding the consideration to approximate the role of these two major events in the world crude oil market. In this regard, the former could be possibly captured by the oil production spread whereas the latter may be possibly approximated by the convenience yield spread.

As previously stated, the variation in the oil futures differential can be attributed to these dynamics during the period 2011 onwards. Rising crude oil flows from tight (shale) oil formations (Bakken in North Dakota and Eagle Ford in Texas) played a key role in

\footnotetext{
${ }^{17}$ Information can be found in EIA website: https://www.eia.gov/energyexplained/index.cfm?page=oil_use and https://www.eia.gov/todayinenergy/detail.php?id=12691
} 
explaining transportation bottlenecks in Cushing, the storage hub for WTI and caused the price of WTI to trade at a significant large discount relative to Brent.

Furthermore, the continuous political instability in the Middle East plausibly caused an increased uncertainty about future oil supply shortfalls which is considered as a precautionary oil demand shock and signifies the convenience yield which incorporates the need of insurance against unexpected disruptions of oil supply. Due to the fact that the Middle Eastern oil production is priced relative to Brent, the geopolitical tensions could have potentially contributed to the higher price level of the Brent crude oil relative to the WTI.

\subsection{Robustness checks}

To evaluate the stability of our findings, firstly we estimate our regression models using the US Treasury bill rate in the construction of the convenience yield instead of the LIBOR rate. Specifically, a shorter time period sample that runs from 2001:8 to 2016:12 is employed only for the nearby month futures contract. The choice of this sample period is motivated by the data availability. Overall, the results are qualitatively similar to the main study findings for the 1-month, the 3-month and the 6-month futures contracts ${ }^{18}$.

Secondly, we employ the SUR approach proposed by Zellner (1962) in order to capture the contemporaneous correlation of the error terms among the three linear regression equations. Thus, we estimate a set of simultaneous equations coefficients by combining information among them. Table 7 reports the results. In general, the results appear to validate the singleequation approach, particularly for the contracts near to maturity (1-month and 3-month). Importantly, the signs of the estimated coefficients remain unchanged.

\section{[PLEASE INSERT TABLE 7 HERE]}

In addition, it seems that the oil futures differential is not affected by the aforementioned determinants to the same extent within different lengths to maturity. This is indicative of the fact that different information is provided among the maturities of 1-month, 3-month and 6month contracts, which in turn implies that each equation contributes to different responses regarding the predictive power of the corresponding determinants. Our results in Table 8 show that the effect of the convenience yield spread is statistically different across the 1month, 3-month and 6-month contracts. Notably, the convenience yield spread has a larger effect for shorter contracts. A plausible explanation is that oil inventories in a shorter-run can be regarded as more important by oil users (e.g. refineries) than in a longer-run. On the other

\footnotetext{
${ }^{18}$ The estimated results are not reported, but are available upon request.
} 
hand, the effects SCO, DSPR, SOI and STV do not seem to be significantly different across the three maturities.

\section{[PLEASE INSERT TABLE 8 HERE]}

\subsection{The Globalisation-regionalisation hypothesis}

Based on the aforementioned preliminary results, we report that the oil futures differential is stationary in level. It is evident that the oil futures prices of WTI and Brent are linked closely together with a structural break. This result is supported by Wilmot (2013) who finds that regional crude oil markets of different or similar grades are linked with a structural break. Since the two oil futures markets move together, the oil futures market is globalised in the long-run. Although evidence suggests that the two oil futures prices move together in the long-run, there is no evidence that the oil futures market is globalised in the short-run. In this respect, we employ a standard F test in order to test for joint significance of the determinants of the oil futures differentials for the 1-month, 3-month and 6-month contracts, which can be considered to belong in the short-run period. Specifically, we seek to ascertain to what extent oil market fundamentals and financial variables contribute to price disparities between WTI and Brent futures prices in the short-run.

In order to test the globalisation-regionalisation hypothesis in the oil futures market, a standard $\mathrm{F}$ test has been employed ${ }^{19}$. The choice of this test is justified by the fact that we seek to determine the extent to which the set of our oil-market specific and oil-futures market specific determinants have predictive power to explain jointly variations in the oil futures differential. The $\mathrm{F}$ test examines the null $\alpha_{2}=\cdots=\alpha_{6}=0$. Failure to reject the null endorses the globalisation hypothesis in the world oil futures market. If the null is rejected, then the world oil futures market is regionalised or segmented. The F statistic reported in Table 9 always falls in the critical region of the null and therefore, the null is rejected regardless the maturity of the futures contract. Indeed, collectively the corresponding determinants can be regarded as significant predictors since they result in explaining a significant amount of variation between WTI and Brent futures prices and consequently they exercise a significant impact on the oil futures differential.

\section{[PLEASE INSERT TABLE 9 HERE]}

Therefore, our results are in line with Milonas and Henker (2001) who indicate that WTI and Brent oil futures prices are not fully integrated, Liu et al. (2015) who report a decreasing level of co-integration between Brent and WTI futures markets and Fattouh (2010) who reveals

\footnotetext{
${ }^{19}$ Technical details for the use of the standard $\mathrm{F}$ test are available in econometric analysis text books (see, for example, Brooks, 2014).
} 
that oil markets are not necessarily integrated in every time period. We provide evidence supporting the hypothesis that the world oil futures market can be influenced by regional logistical bottlenecks, geopolitical turmoil and financial activity in the short-run which reduces the degree of integration and suggests that the oil futures market does not appear to be globalised in the short-run. However, these factors exhibit a relatively short-lived effect since the oil futures market adjusts and absorbs the temporary imbalances, reduces the uncertainty about unexpected oil supply shortfalls and drives the volatility between the WTI and Bent oil futures prices at lowest levels.

\section{Conclusion}

In this paper, we investigate the role of potential determinants of the WTI/Brent oil futures price differential for the two major benchmarks of crude oil, namely West Texas Intermediate (WTI) and Brent and subsequently the globalisation-regionalisation hypothesis in the oil futures market based on the WTI/Brent oil futures price differential. A limited number of studies focus on macroeconomic indicators, oil market fundamentals and financial market variables (see Büyükşahin et al., 2013). Our research extends this strand of literature by investigating the effects of additional factors such as the spread of WTI/Brent convenience yield, the spread of WTI/Brent oil consumption, the spread of WTI/Brent oil production, the spread of WTI/Brent open interest and the spread of WTI/Brent trading volume on the WTI/Brent oil futures price differential. The choice of WTI and Brent benchmarks is based on the fact that both are global dominants of crude oil futures trading markets. Moreover, we focus on the oil futures differential since futures prices are more informative than spot prices. We use monthly data covering the period from January 1993 to December 2016.

Our findings are briefly summarised as follows. First, the convenience yield spread explains the variability in the oil futures differential for the nearest and the 3-month to maturity contracts. Second, the oil production spread affects the oil futures differential for the nearby month, the 3-month and the 6-month to maturity contracts whereas the oil consumption spread acts as a driver of the oil futures differential only for the 6-month contract. Third, the open interest spread influences the oil futures differential for the 3-month and the 6-month to maturity contracts. Fourth, the trading volume spread exercises a significant impact on the oil futures differential for the nearest to expiration and the 3-month to maturity contracts. We conclude that the oil convenience yield, the physical oil market fundamental factors (oil production and oil consumption) and the oil futures market variables (open interest and trading volume) drive a significant wedge between the WTI and Brent oil futures prices, 
which is indicative of a regionalised oil futures market in the short-run. These variables are significant determinants of the oil futures differential.

As far as the globalisation-regionalisation hypothesis between the WTI and Brent in the oil futures market is concerned, any deviation of the WTI or Brent from the long-run cointegration relationship would be interpreted as evidence of a regionalised oil futures market. Although WTI and Brent represent the two leading references for oil futures markets globally, the aforementioned recent developments in crude oil market since late-2010, with a particular attention to regional logistical bottlenecks, seem to have a significant impact on the WTI as a leading global benchmark of the crude oil futures market and make it a less reliable indicator for pricing crude oil internationally.

However, the WTI futures contracts are the most liquid and actively traded contracts in the world oil futures market which clearly explains the adoption of WTI as a valuable financial asset by energy traders in financial markets. Thus, we consider the importance of WTI and suggest that any large asymmetry from the part of WTI which contributes to a significant divergence between the two benchmarks signifies that the world oil futures market is indeed segmented. The extent to which the international oil futures market is integrated and the deviation of WTI futures price does not imply regionalisation but simply reflect the deviation of the US oil futures market from the rest of the world would be an avenue for further research, as it falls beyond the scope of this study.

In the same line of reasoning, Brent is considered as a leading crude oil benchmark because it serves as a reference for two-thirds of the world's internationally traded crude oil. This can be attributed to the fact that it is a waterborne crude oil and does not affected by pipeline bottlenecks. This dynamic can be further endorsed by the increasing importance that Brent appears to play in oil futures market during the recent years. However, this potential dominance does not appear to be permanent. Indeed, oil production in the North Sea, the located field for Brent continues to decline and the extent to which Brent will be replaced by an Asian based oil benchmark due to the growing demand for oil in Asian markets raise concerns about Brent crude's to serve as a leading benchmark. This provides evidence to support the argument that regionalisation in international oil futures market will be likely to occur from the part of Brent over time.

In this regard, an interesting question that the future study might address is the consideration of additional crude oil benchmarks further to WTI and Brent such as the Dubai/Oman in order to get a more thorough picture of the degree in which the state of the international oil futures market is globalised or regionalised. Since we examine WTI and Brent, we cannot 
argue that any significant divergence in their differential should be indicative of WTI or Brent separation from the rest of the world. Furthermore, it would be interesting for future research to employ time-varying parameter models in order to examine whether the oil futures differential is affected by physical market and financial market factors (for example, oil consumption, oil production, open interest) at different time periods. In addition, based on the findings of this research, another interesting direction for future study is to test the ability of our significant determinants to forecast the deviations between the two crude oil benchmarks and consequently to evaluate the future state of the oil futures market (globalised or regionalised).

Finally, it would be interesting to examine the impact of renewable energy sources in production and consumption (with a particular reference to the US and the European Union energy markets) on the total energy sources including petroleum and therefore oil production and consumption. The increasing use of renewable energy sources could influence the use of fossil fuels and consequently lead to reduced levels of oil production and consumption and further affect the convenience yield which regarded to be significant determinants of the oil futures differential. In addition, legislation, regulations and political environment are likely to have significant implications regarding the subject field.

Overall, in this study we offer a better understanding of the globalisation-regionalisation hypothesis in the oil futures market by examining the relationship between the oil futures differential, convenience yields and potential crude oil (fundamental and financial) predictors. Our findings are important for investors and traders in both WTI and Brent crude oil futures markets who are trading oil futures contracts and seeking to manage asset portfolios and protect themselves against adverse price movements in the future. In addition, our findings should be utilised by market participants when they are attempting to identify in what extent the oil futures market is affected by the physical oil market factors of supply and demand.

\section{Acknowledgements}

We like to thank the editor (I. Chatziantoniou) and the two anonymous referees for their invaluable comments and suggestions on a previous version of this paper. We would also like to thank Mark Cummins for his constructive comments and suggestions which helped us to improve the scope and clarity of the paper. Finally, we thank the participants of the $13^{\text {th }}$ INFINITI Conference on International Finance, the Portsmouth-Fordham Conference on Banking and Finance and the $11^{\text {th }}$ Postgraduate Research Conference at Portsmouth 
University for their useful comments. The usual disclaimer applies for any remaining errors and omissions.

\section{References}

Adelman, M.A. (1984). International oil agreements. The Energy Journal, 5, 1-9.

Alquist, R., \& Arbatli, E. (2010). Crude oil futures: A crystal ball? Bank of Canada Review, 2010 (Spring), 3-11.

Alquist, R., Bauer, G. H., \& Díez de los Ríos, A. (2014). What does the convenience yield curve tell us about the crude oil market? (No. 2014-42). Bank of Canada Working Paper.

Alquist, R., \& Kilian, L. (2010). What do we learn from the price of crude oil futures?. Journal of Applied Econometrics, 25(4), 539-573.

Arouri, M.E., Jouini, J., \& Nguyen, D.K. (2011). Volatility spillovers between oil prices and stock sector returns: Implications for portfolio management. Journal of International Money and Finance, 30(7), 1387-1405.

Bai, J., \& Perron, P. (1998). Estimating and testing linear models with multiple structural changes. Econometrica, 47-78.

Barsky, R., \& Kilian, L. (2004). Oil and the macroeconomy since the 1970s. The Journal of Economic Perspectives, 18, 115-134.

Bekiros, S.D., \& Diks, G.H. (2008). The relationship between crude oil spot and futures prices: Cointegration, linear and nonlinear causality. Energy Economics, 30, 26732685.

Büyükşahin, B., Lee, T.K., Moser, J.T., \& Robe, M.A. (2013). Physical markets, paper markets and the WTI-Brent spread. Energy Journal, 34(3), 129-151.

Brooks, C. (2014). Introductory econometrics for finance. Cambridge university press.

Candelon, B., Joëts, M., \& Tokpavi, S. (2013). Testing for Granger causality in distribution tails: An application to oil markets integration. Economic Modelling, 31, 276-285.

Caumon, F., \& Bower, J. (2004). Redefining the convenience yield in the North Sea Crude oil market. Oxford Institute for Energy Studies, Working Paper Series No. WPM 28.

Chang, K.L. (2012). Volatility regimes, asymmetric basis effects and forecasting performance: An empirical investigation of the WTI crude oil futures market. Energy Economics 34(1), 294-306. 
Chang, C.L., McAleer, M., \& Tansuchat, R. (2010). Analyzing and forecasting volatility spillovers, asymmetries and hedging in major oil markets, Energy Economics, 32, $1445-1455$.

Chevillon, G., \& Rifflart, C. (2009). Physical market determinants of the price of crude oil and the market premium. Energy Economics, 31(4), 537-549.

Choi, K., \& Hammoudeh, S. (2010). Volatility behavior of oil, industrial commodity and stock markets in a regime-switching environment. Energy Policy, 38(8), 4388-4399.

Chordia, T., \& Swaminathan, B. (2000). Trading volume and cross-autocorrelations in stock returns. Journal of Finance, 55, 913-935.

Dickey, D.A., \& Fuller, W.A. (1981). Likelihood ratio statistics for autoregressive time series with a unit root. Econometrica, 49, 1057-1072.

Duan, C., \& Lin, W. (2010). Raw material convenience yields and business cycle. Handbook of Quantitative Finance and Risk Management, pp. 915-931.

Duffie, D., \& Stein, J. C. (2015). Reforming LIBOR and other financial market benchmarks. The Journal of Economic Perspectives, 29(2), 191-212.

Elder, J., Miao, H., \& Ramchander, S. (2014). Price discovery in crude oil futures. Energy Economics, 46, S18-S27.

Fama, E.F., \& French, K.R. (1988). Business cycles and the behavior of metals prices. The Journal of Finance, 43(5), 1075-1093.

Fattouh, B. (2010). The dynamics of crude oil price differentials. Energy Economics, 32(2), $334-342$.

Filis, G., Degiannakis, S., \& Floros, C. (2011). Dynamic correlation between stock market and oil prices: The case of oil-importing and oil-exporting countries. International Review of Financial Analysis, 20(3), 152-164.

Gospodinov, N., \& Ng, S. (2013). Commodity prices, convenience yields, and inflation. Review of Economics and Statistics 95(1), 206-219.

Graham-Higgs, J., Rambaldi, A., \& Davidson, B. (1999). Is the Australian wool futures market efficient as a predictor of spot prices? Journal of Futures Markets, 19(5), $565-582$.

Gülen, S.G. (1997). Regionalization in the world crude oil market. The Energy Journal, 18, 109-126.

Gülen, S.G. (1999). Regionalization in the world crude oil market: further results. The Energy Journal, 20, 125-139. 
Hamilton, J.D. (2008). Understanding crude oil prices. National Bureau of Economic Research, Working Paper Series No. w14492.

Hammoudeh, S., Bhar, R., \& Thompson, M. A. (2010). Re-examining the dynamic causal oil macro-economy relationship. International Review of Financial Analysis, 19(4), 298-305.

Hammoudeh, S. M., Ewing, B. T., \& Thompson, M. A. (2008). Threshold cointegration analysis of crude oil benchmarks. The Energy Journal, 79-95.

Hammoudeh, S., \& Li, H. (2005). Oil sensitivity and systematic risk in oil-sensitive stock indices. Journal of Economics and Business, 57(1), 1-21.

Hammoudeh, S., Li, H., \& Jeon, B. (2003). Causality and volatility spillovers among petroleum prices of WTI, gasoline and heating oil in different locations. The North American Journal of Economics and Finance, 14(1), 89-114.

Hammoudeh, S., \& Yuan, Y. (2008). Metal volatility in presence of oil and interest rate shocks. Energy Economics, 30(2), 606-620.

Heidorn, T., Mokinski, F., Rühl, C., \& Schmaltz, C. (2015). The impact of fundamental and financial traders on the term structure of oil. Energy Economics, 48, 276-287.

Hong, H., \& Yogo, M. (2012). What does futures market interest tell us about the macroeconomy and asset prices? Journal of Financial Economics, 105(3), 473-490.

Hull, J. (2012). Options, futures, and other derivatives, 8th Edition. (New York: Pearson Prentice Hall).

Jennings, R.H., Starks, L., \& Fellingham, J. (1981). An equilibrium model of asset trading with sequential information arrival. Journal of Finance, 36, 143-161.

Ji, Q., \& Fan, Y. (2015). Dynamic integration of world oil prices: A reinvestigation of globalisation vs. regionalisation. Applied Energy, 155, 171-180.

Kao, C.W., \& Wan, J.Y. (2012). Price discount, inventories and the distortion of WTI benchmark. Energy Economics, 34(1), 117-124.

Kilian, L. (2009). Not all oil price shocks are alike: Disentangling demand and supply shocks in the crude oil market. The American Economic Review, 1053-1069.

Kilian, L. (2016). The impact of the shale oil revolution on US oil and gasoline prices. Review of Environmental Economics and Policy, 10(2), 185-205.

Kilian, J \& Park, C. (2009). The Impact of Oil Price Shocks on the U.S. Stock Market, International Economic Review, 50(4), 1267-1287.

Kleit, A. N. (2001). Are regional oil markets growing closer together?: An arbitrage cost approach. The Energy Journal, 1-15. 
Knetsch, T.A. (2007). Forecasting the price of crude oil via convenience yield predictions. Journal of Forecasting, 26(7), 527-549.

Lean, H.H., McAleer, M., \& Wong, W.K. (2010). Market efficiency of oil spot and futures: A mean-variance and stochastic dominance approach. Energy Economics, 32, 979986.

Liu, W. M., Schultz, E., \& Swieringa, J. (2015). Price dynamics in global crude oil markets. Journal of Futures Markets, 35(2), 148-162.

Maghyereh, A. (2004). Oil price shocks and emerging stock markets: a generalized VAR approach. International Journal of Applied Econometrics and Quantitative Studies, $1(2), 27-40$.

Mellios, C., \& Six, P. (2011). The traditional hedging model revisited with a nonobservable convenience yield. Financial Review, 46(4), 569-593.

Miffre, J. (2004). The conditional price of basis risk: an investigation using foreign exchange instruments. Journal of Business Finance \& Accounting, 31(7-8), 1043-1068.

Milonas, N., \& Henker, T. (2001). Price spread and convenience yield behaviour in the international oil markets. Applied Financial Economics, 11, 23-26.

Phillips, P.C., \& Perron, P. (1988). Testing for a unit root in time series regression. Biometrika, 75(2), 335-346.

Reboredo, J.C. (2011). How do crude oil prices co-move?: A copula approach. Energy Economics, 33(5), 948-955.

Speight, J.G. (2011). An introduction to petroleum technology, economics, and politics. (John Wiley \& Sons).

Westgaard, S., Estenstad, M., Seim, M., \& Frydenberg, S. (2011). Co-integration of ICE gas oil and crude oil futures. Energy Economics, 33(2), 311-320.

Weiner, R.J. (1991). Is the world oil market one great pool? The Energy Journal, 12, 95-107.

Wilmot, N.A. (2013). Cointegration in the oil market among regional blends. International Journal of Energy Economics and Policy, 3(4), 424-433.

Zellner, A. (1962). An efficient method of estimating seemingly unrelated regressions and tests for aggregation bias. Journal of the American statistical Association, 57(298), 348-368.

Zivot, E., \& Andrews, D.W. (1992). Further evidence on the Great Crash, the oil-price shock, and the unit-root hypothesis. Journal of Business \& Economic Statistics, 10(0), 251-270. 


\section{FIGURES}

Figure 1: Time series plots for WTI and Brent oil futures prices
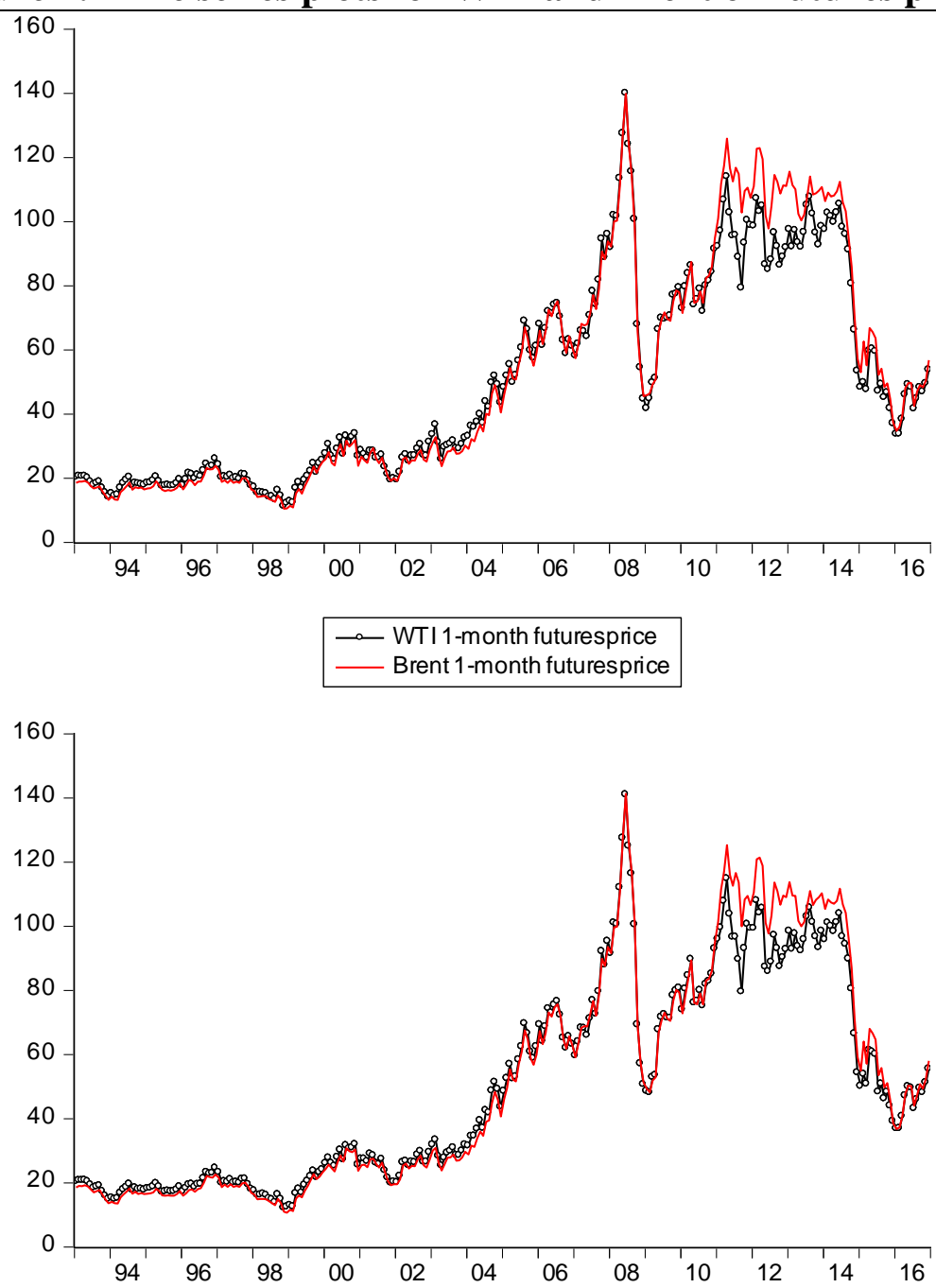

- WTI3-month futuresprice
— Brent 3-month futuresprice

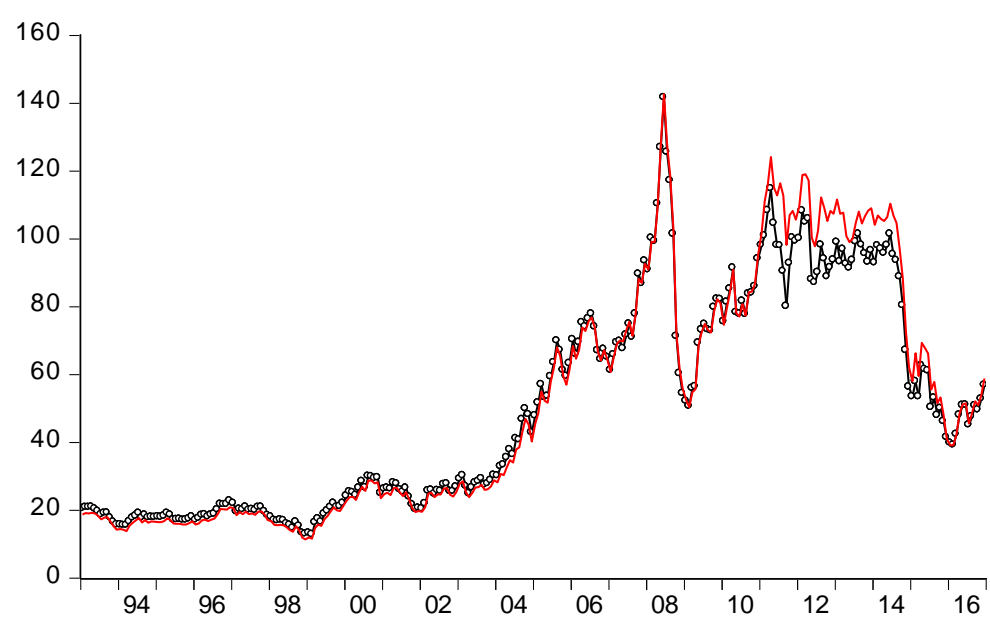

W- WT 6-month futuresprice Brent 6-month futuresprice

Note: This Figure depicts variation over time in the WTI and Brent futures prices. The sample period runs from January 1993 to December 2016. 
Figure 2: Time series plots for the WTI/Brent oil futures price differential SFP M1

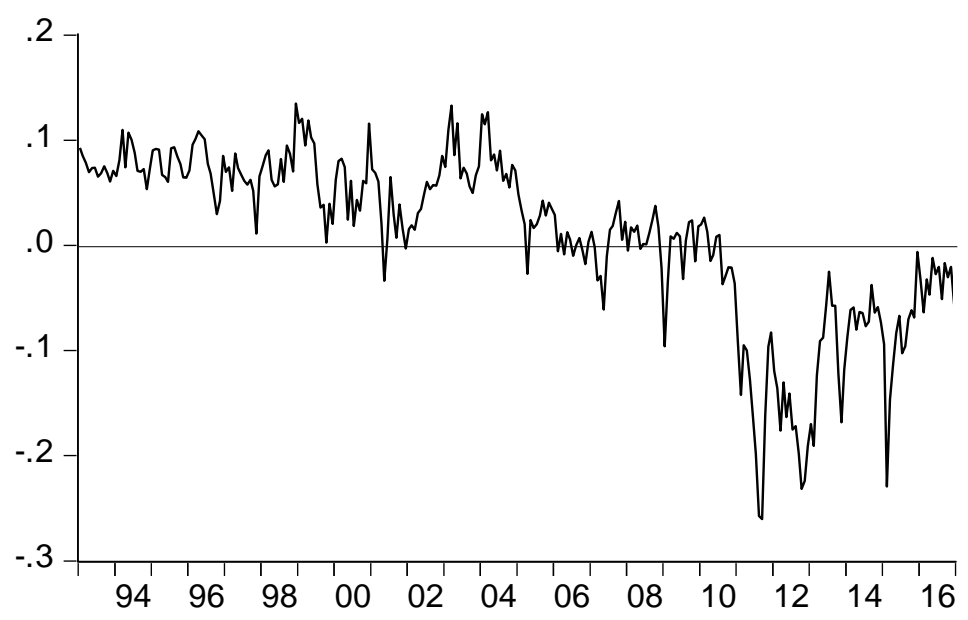

SFP M3

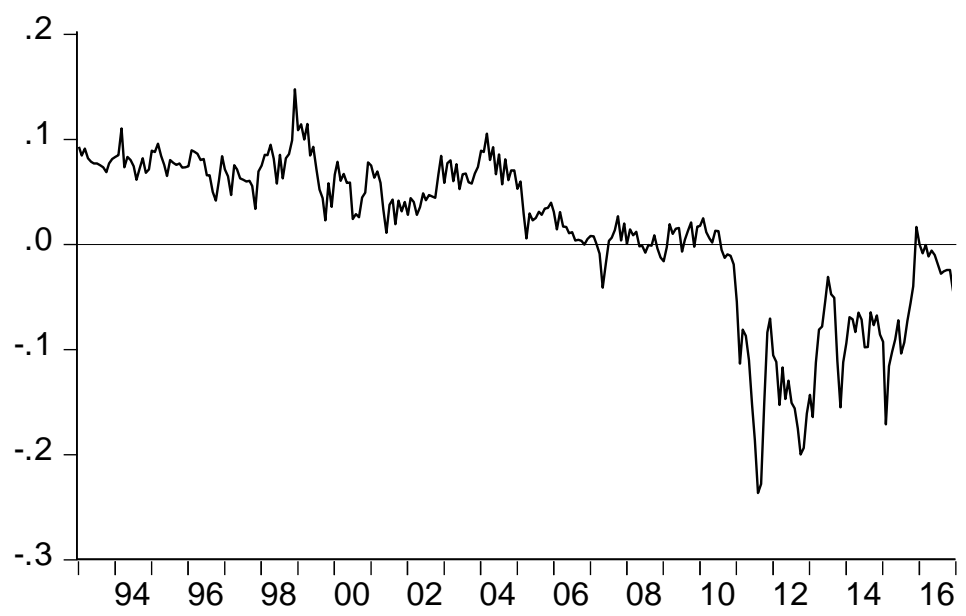

SFP M6

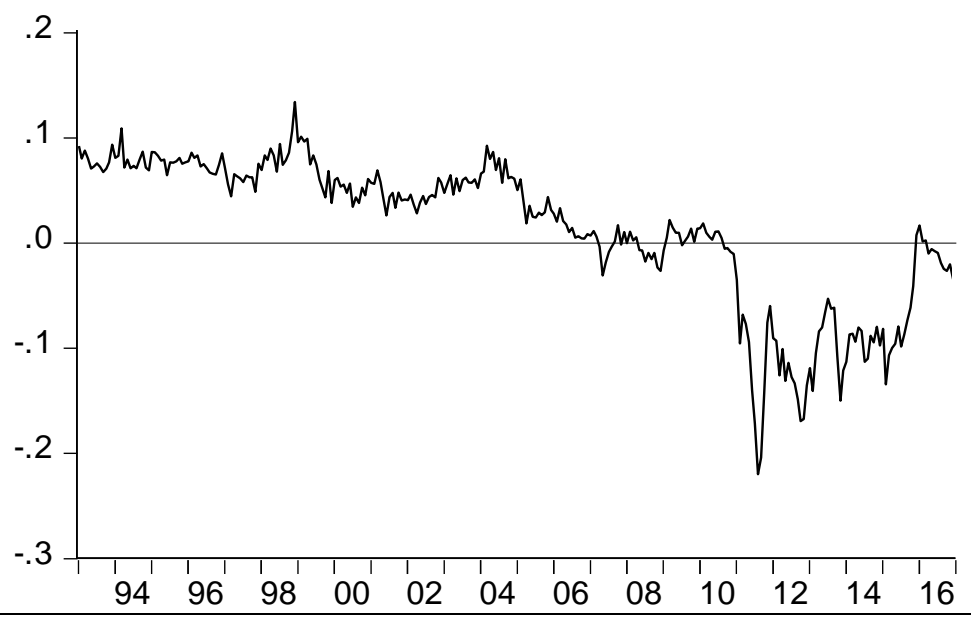


Note: This Figure depicts variation over time in the WTI/Brent oil futures differential (SFP). $\mathrm{M} 1=$ one-month futures contract, $\mathrm{M} 3=$ three-month futures contract, M6 = six-month futures contract. The sample period runs from January 1993 to December 2016. 
TABLES

\section{Table 1: Descriptive statistics}

Panel A: Oil futures differential, convenience yield spread at 1,3 and 6 months to maturity and oil consumption spread.

\begin{tabular}{|c|c|c|c|c|c|c|c|}
\hline & SFP M1 & SFP M3 & SFP M6 & SCY M1 & SCY M3 & SCY M6 & $\mathrm{SCO}$ \\
\hline Mean & 0.0094 & 0.0124 & 0.0126 & 0.0083 & 0.0051 & 0.0050 & 0.8867 \\
\hline Median & 0.0243 & 0.0289 & 0.0347 & 0.0064 & 0.0042 & 0.0049 & 0.9061 \\
\hline Maximum & 0.1348 & 0.1465 & 0.1328 & 0.0933 & 0.0913 & 0.1259 & 1.0648 \\
\hline Minimum & -0.2604 & -0.2377 & -0.2209 & -0.0795 & -0.1164 & -0.1309 & 0.6853 \\
\hline Std. Dev. & 0.0807 & 0.0736 & 0.0695 & 0.0253 & 0.0279 & 0.0333 & 0.1010 \\
\hline Skewness & -1.0777 & -1.1212 & -1.0296 & 0.3070 & -0.0072 & -0.0751 & -0.2365 \\
\hline Kurtosis & 3.7644 & 3.6771 & 3.2532 & 4.3852 & 4.5035 & 4.3312 & 1.9771 \\
\hline Jarque-Bera & $62.7642 * * *$ & $65.8398 * * *$ & $51.6496 * * *$ & $27.5498 * * *$ & $27.1272 * * *$ & $21.5345^{* * * *}$ & $15.2400 * * *$ \\
\hline Probability & 0.0000 & 0.0000 & 0.0000 & 0.0000 & 0.0000 & 0.0000 & 0.0005 \\
\hline \multicolumn{8}{|c|}{ Panel B: Open interest spread, trading volume spread at 1,3 and 6 months to maturity and oil production spread. } \\
\hline & SOI M1 & SOI M3 & SOI M6 & STV M1 & STV M3 & STV M6 & SPR \\
\hline Mean & 0.0317 & 0.3184 & 0.5954 & 0.4991 & 0.4693 & 0.6860 & 0.6116 \\
\hline Median & 0.0708 & 0.3650 & 0.5970 & 0.6029 & 0.4397 & 0.6728 & 0.4380 \\
\hline Maximum & 1.9522 & 1.9606 & 2.8793 & 1.2007 & 1.9519 & 2.6751 & 1.6066 \\
\hline Minimum & -1.0991 & -1.1320 & -1.0786 & -0.3974 & -0.6961 & -1.1227 & 0.1333 \\
\hline Std. Dev. & 0.3676 & 0.4603 & 0.5988 & 0.3758 & 0.5660 & 0.7125 & 0.4578 \\
\hline Skewness & 0.1696 & -0.2288 & 0.3401 & -0.7908 & 0.1843 & 0.3079 & 0.9830 \\
\hline Kurtosis & 5.3830 & 3.6664 & 3.8589 & 2.7997 & 2.3610 & 2.8550 & 2.5111 \\
\hline Jarque-Bera & $69.5233 * * *$ & $7.8402^{* * *}$ & $14.4029 * *$ & $30.5011 * * *$ & $6.5299 * *$ & $4.8028 *$ & $49.2488 * * *$ \\
\hline Probability & 0.0000 & 0.0198 & 0.0007 & 0.0000 & 0.0382 & 0.0906 & 0.0000 \\
\hline
\end{tabular}

Note: This table summarises descriptive statistics (sample mean, median, maximum, minimum, standard deviation, skewness, kurtosis, the Jarque-Bera test statistic, and the p-value associated to the Jarque-Bera test statistic) of SFP, SCY and SCO (Panel A), SOI, STV and SPR $($ Panel B). SFP $=$ WTI/Brent oil futures price differential, SCY $=$ WTI $/$ Brent convenience yield spread, SOI $=$ WTI $/$ Brent open interest spread, STV = WTI/Brent trading volume spread, SCO = WTI/Brent oil consumption spread, SPR = WTI/Brent oil production spread, M1 = one-month futures contract, M3 = three-month futures contract, M6 = six-month futures contract. Asterisk * $(* *, * * *)$ denotes the $10 \%(5 \%$, 1\%) significance level. The sample period runs from January 1993 to December 2016. 
Table 2: Augmented Dickey-Fuller (1981), Philips-Perron (1988) and Zivot-Andrews (1992) unit root tests.

\begin{tabular}{|c|c|c|c|c|c|c|}
\hline \multicolumn{7}{|c|}{ Panel A - ADF test } \\
\hline & $\mathrm{C}$ & & $\mathrm{C} \& \mathrm{~T}$ & & $\mathrm{~N}$ & \\
\hline WF M1 & -1.9510 & & -2.6510 & & -0.7701 & \\
\hline WF M3 & -1.8621 & & -2.5520 & & -0.7026 & \\
\hline WF M6 & -1.7839 & & -2.4683 & & -0.6435 & \\
\hline BF M1 & -1.8152 & & -2.4932 & & -0.7329 & \\
\hline BF M3 & -1.7695 & & -2.4535 & & -0.6931 & \\
\hline BF M6 & -1.7109 & & -2.3899 & & -0.6470 & \\
\hline SFP M1 & -3.0148 & $* *$ & -4.7496 & $* * *$ & -3.0364 & $* * *$ \\
\hline SFP M3 & -2.3414 & & -3.7757 & $* *$ & -2.3820 & $* *$ \\
\hline SFP M6 & -2.0608 & & -3.3973 & $*$ & -2.1153 & $* *$ \\
\hline SCY M1 & -8.3123 & $* * *$ & -8.3002 & $* * *$ & -7.5233 & $* * *$ \\
\hline SCY M3 & -10.5766 & $* * *$ & -10.6720 & $* * *$ & -10.3510 & $* * *$ \\
\hline SCY M6 & -8.5793 & $* * *$ & -8.6728 & $* * *$ & -8.4708 & $* * *$ \\
\hline SOI M1 & -1.7973 & & -3.1596 & $*$ & -1.9353 & $*$ \\
\hline SOI M3 & -2.8536 & $*$ & -5.1762 & $* * *$ & -2.0198 & $* *$ \\
\hline SOI M6 & -2.8517 & $*$ & -7.6895 & $* * *$ & -2.4716 & $* *$ \\
\hline STV M1 & -2.0027 & & -3.8989 & $* *$ & -1.6602 & $*$ \\
\hline STV M3 & -2.0297 & & -3.0431 & & -2.3436 & $* *$ \\
\hline STV M6 & -2.2944 & & -4.3515 & $* * *$ & -2.2839 & $* *$ \\
\hline $\mathrm{SCO}$ & -1.4094 & & -5.0578 & $* * *$ & 1.3078 & \\
\hline SPR & 1.1749 & & -2.7051 & & 2.0786 & \\
\hline \multicolumn{7}{|c|}{ Panel B - PP test } \\
\hline & $\mathrm{C}$ & & $\mathrm{C} \& \mathrm{~T}$ & & $\mathrm{~N}$ & \\
\hline WF M1 & -1.8716 & & -2.3591 & & -0.7450 & \\
\hline WF M3 & -1.7789 & & -2.2612 & & -0.6721 & \\
\hline WF M6 & -1.7247 & & -2.2557 & & -0.6004 & \\
\hline BF M1 & -1.6550 & & -1.5935 & & -0.6288 & \\
\hline BF M3 & -1.6143 & & -1.8902 & & -0.6204 & \\
\hline BF M6 & -1.6057 & & -1.8324 & & -0.5763 & \\
\hline SFP M1 & -2.8952 & $* *$ & -4.6700 & $* * *$ & -2.9166 & $* * *$ \\
\hline SFP M3 & -2.0088 & & -3.6271 & $* *$ & -2.0685 & $* *$ \\
\hline SFP M6 & -1.7399 & & -3.3107 & $*$ & -1.8219 & $*$ \\
\hline SCY M1 & -14.0897 & $* * *$ & -14.0778 & $* * *$ & -13.7397 & $* * *$ \\
\hline SCY M3 & -10.8059 & $* * *$ & -10.8335 & $* * *$ & -10.7392 & $* * *$ \\
\hline SCY M6 & -8.5247 & $* * *$ & -8.6288 & $* * *$ & -8.3879 & $* * *$ \\
\hline SOI M1 & -10.4297 & $* * *$ & -15.7848 & $* * *$ & -10.3767 & $* * *$ \\
\hline SOI M3 & -6.7137 & $* * *$ & -12.1751 & $* * *$ & -4.5194 & $* * *$ \\
\hline SOI M6 & -7.3565 & $* * *$ & -12.6282 & $* * *$ & -4.0774 & $* * *$ \\
\hline STV M1 & -3.2619 & $* *$ & -7.0202 & $* * *$ & -2.3469 & $* *$ \\
\hline STV M3 & -4.0251 & $* * *$ & -10.1018 & $* * *$ & -3.8999 & $* * *$ \\
\hline
\end{tabular}




\begin{tabular}{ccccccc} 
STV M6 & -6.4948 & $* * *$ & -13.6656 & $* * *$ & -4.2980 & $* * *$ \\
SCO & -1.3777 & & -4.8127 & $* * *$ & 2.1368 & \\
SPR & 0.9326 & & -2.7937 & & 1.7253 & \\
\hline \multicolumn{7}{c}{ Panel C - ZA test } \\
SFP M1 & -5.8693 & $* * *$ & -7.7013 & $* * *$ & -5.0190 & \\
SFP M3 & -4.8116 & $* *$ & -7.1282 & $* * *$ & -4.0245 & $*$ \\
SFP M6 & -4.0552 & $* *$ & -6.6180 & $* * *$ & -3.4131 & $* *$ \\
SCY M1 & -6.1770 & $* * *$ & -6.3341 & $* *$ & -5.9618 & $* * *$ \\
SCY M3 & -11.1622 & $* * *$ & -11.4873 & $* * *$ & -11.0264 & $* * *$ \\
SCY M6 & -9.1877 & $* * *$ & -9.5835 & $* * *$ & -8.9150 & $* *$ \\
SOI M1 & -6.3439 & $* * *$ & -6.4460 & $* * *$ & -5.8495 & $* * *$ \\
SOI M3 & -6.8665 & $* * *$ & -6.8856 & $* * *$ & -6.1088 & $* * *$ \\
SOI M6 & -6.0744 & $* * *$ & -6.2039 & $* * *$ & -5.1827 & $* * *$ \\
STV M1 & -4.2999 & $* * *$ & -5.4440 & $* * *$ & -3.0423 & \\
STV M3 & -5.7855 & $* *$ & -6.8295 & $* * *$ & -6.2879 & $* * *$ \\
STV M6 & -6.7590 & $* * *$ & -7.3687 & $* * *$ & -6.7085 & $* * *$ \\
SCO & -5.6936 & $* * *$ & -5.6834 & $* * *$ & -3.9760 & \\
SPR & -4.3066 & $* * *$ & -2.7964 & & -2.5360 & \\
\hline
\end{tabular}

Note: For the ADF, PP and ZA unit root tests the null hypothesis is that the series features a unit root. In the ADF and PP tests, $\mathrm{C}$ denotes constant term, C\&T denotes constant and time trend, $\mathrm{N}$ indicates no deterministic component in the test equation. In the ZA test equation, a constant and a linear time trend are included. $\mathrm{C}$ allows for a break in the constant, $\mathrm{T}$ allows for a break in the trend, and C\&T allows for a break in both the constant and the time trend. WF $=$ WTI futures price, $\mathrm{BF}=$ Brent futures price, $\mathrm{SFP}=$ WTI/Brent oil futures price differential, SCY $=$ WTI/Brent convenience yield spread, SOI $=\mathrm{WTI} /$ Brent open interest spread, $\mathrm{STV}=\mathrm{WTI} /$ Brent trading volume spread, $\mathrm{SCO}=$ WTI/Brent oil consumption spread, SPR $=$ WTI/Brent oil production spread, M1 = onemonth futures contract, $\mathrm{M} 3=$ three-month futures contract, $\mathrm{M} 6=$ six-month futures contract. Asterisk * $(* *, * * *)$ denotes the $10 \%(5 \%, 1 \%)$ significance level. The sample period runs from January 1993 to December 2016. 


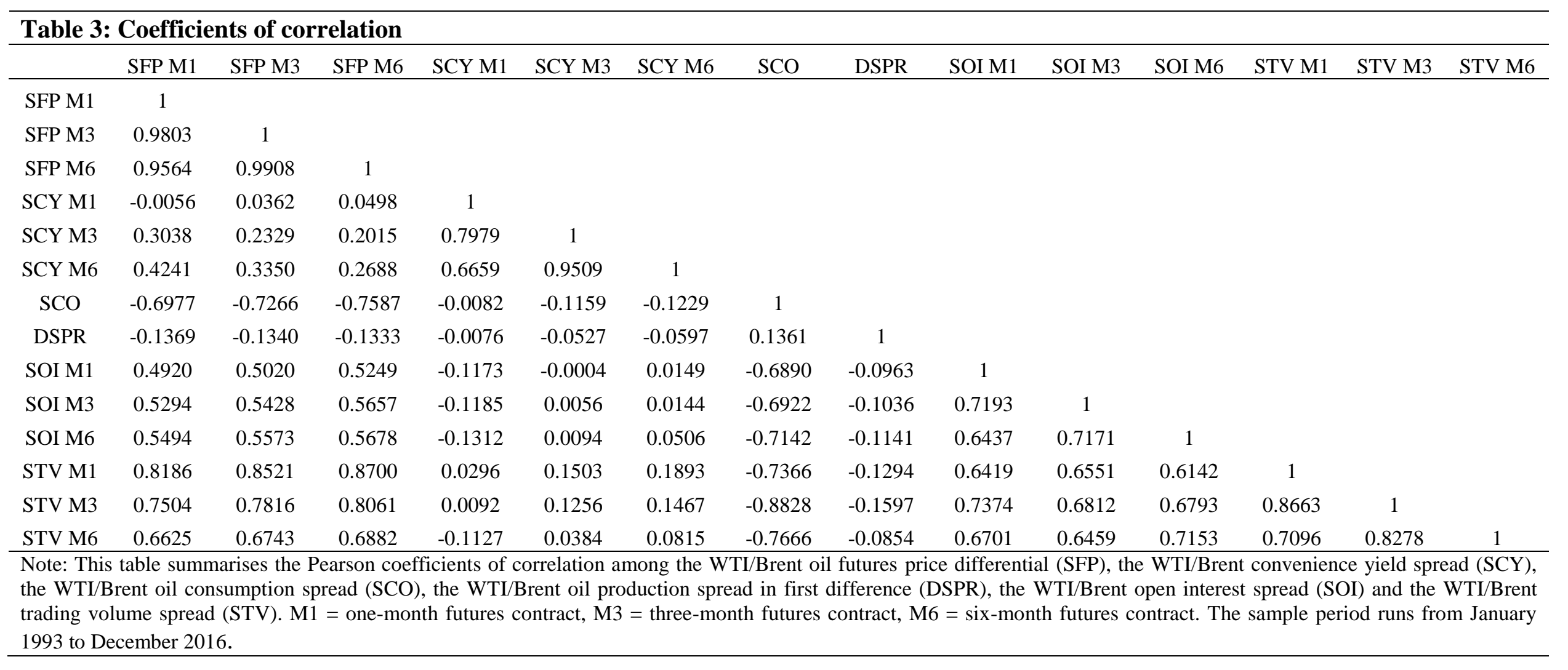




\begin{tabular}{|c|c|c|c|c|c|c|c|c|c|c|c|c|}
\hline Predictors & $(1)$ & & $(2)$ & & (3) & & $(4)$ & & $(5)$ & & $(6)$ & \\
\hline \multirow[t]{2}{*}{ C } & 0.0090 & $* * *$ & 0.0430 & $* *$ & 0.0087 & $* * *$ & 0.0077 & $* * *$ & -0.0039 & & 0.0216 & \\
\hline & $(0.0020)$ & & $(0.0188)$ & & $(0.0021)$ & & $(0.0023)$ & & $(0.0050)$ & & $(0.0202)$ & \\
\hline \multirow[t]{2}{*}{$\mathrm{SFP}(\mathrm{t}-1)$} & 0.8995 & $* * *$ & 0.7984 & $* * *$ & 0.8140 & $* * *$ & 0.8183 & $* * *$ & 0.7740 & $* * *$ & 0.8526 & $* * *$ \\
\hline & $(0.0353)$ & & $(0.0427)$ & & $(0.0334)$ & & $(0.0350)$ & & $(0.0405)$ & & $(0.0421)$ & \\
\hline \multirow[t]{2}{*}{ SCYt } & -0.5282 & $* * *$ & & & & & & & & & -0.5249 & $* * *$ \\
\hline & $(0.0840)$ & & & & & & & & & & $(0.0889)$ & \\
\hline \multirow[t]{2}{*}{ SCOt } & & & -0.0396 & $*$ & & & & & & & -0.0225 & \\
\hline & & & $(0.0206)$ & & & & & & & & $(0.0209)$ & \\
\hline \multirow[t]{2}{*}{ DSPRt } & & & & & -0.0862 & $* * *$ & & & & & -0.0771 & $* * *$ \\
\hline & & & & & $(0.0292)$ & & & & & & $(0.0258)$ & \\
\hline \multirow[t]{2}{*}{ SOIt } & & & & & & & -0.0049 & & & & -0.0090 & \\
\hline & & & & & & & $(0.0059)$ & & & & $(0.0058)$ & \\
\hline \multirow[t]{2}{*}{$\mathrm{STVt}$} & & & & & & & & & 0.0213 & $* *$ & 0.0149 & $* *$ \\
\hline & & & & & & & & & $(0.0083)$ & & $(0.0074)$ & \\
\hline \multirow[t]{2}{*}{ Dt } & -0.0155 & $* * *$ & -0.0238 & $* * *$ & -0.0270 & $* * *$ & -0.0247 & $* * *$ & -0.0188 & $* * *$ & -0.0123 & $* *$ \\
\hline & $(0.0058)$ & & $(0.0055)$ & & $(0.0054)$ & & $(0.0061)$ & & $(0.0060)$ & & $(0.0061)$ & \\
\hline $\mathrm{R}^{2}$ & 0.9157 & & 0.8916 & & 0.8924 & & 0.8908 & & 0.8930 & & 0.9195 & \\
\hline BG & 2.4092 & & 0.5235 & & 0.3701 & & 0.5651 & & 0.7330 & & 1.4486 & \\
\hline $\begin{array}{l}\text { Note: This ta } \\
\text { variables are } \\
\text { (SCOt), the V } \\
\text { dummy varia } \\
\text { Serial Correl } \\
\text { to December }\end{array}$ & $\begin{array}{l}\text { ble reports es } \\
\text { the lagged } \\
\text { VTI/Brent oil } \\
\text { ble that takes } \\
\text { tion (BG) tes }\end{array}$ & $\begin{array}{l}\text { /Brent } \\
\text { ductio } \\
\text { value } \\
\text { e Wal }\end{array}$ & $\begin{array}{l}\text { futures pric } \\
\text { read in first } \\
\text { ) after (befo } \\
\text { atistic is rep }\end{array}$ & d. Ast & $\begin{array}{l}(\mathrm{SFP}(\mathrm{t}-1)) \text {, } \\
\text { SPRt), the W } \\
10(\mathrm{Dt}) . \mathrm{Het} \\
*(* *, * * *)\end{array}$ & tes th & $\begin{array}{l}\text { ariable is th } \\
t \text { convenien } \\
\text { interest spr } \\
\text { robust stan } \\
\%(5 \%, 1 \%)\end{array}$ & l of & $\begin{array}{l}\text { il futures pr } \\
\text { d (SCYt), } t \\
\text { WTI/Brent } \\
\text { reported in } \\
\text { ficance. The }\end{array}$ & $\begin{array}{l}\text { differ } \\
\text { WTI/ } \\
\text { ding v }\end{array}$ & $\begin{array}{l}\text { (SFP). The } \\
\text { oil consum } \\
\text { e spread (ST } \\
\text { For the Breu } \\
\text { runs from J }\end{array}$ & $\begin{array}{l}\text { planatory } \\
\text { on spread } \\
\text {, and the } \\
\text {-Godfrey } \\
\text { lary } 1993\end{array}$ \\
\hline
\end{tabular}




\begin{tabular}{|c|c|c|c|c|c|c|c|c|c|c|c|c|}
\hline Predictors & (1) & & (2) & & (3) & & (4) & & (5) & & (6) & \\
\hline \multirow[t]{2}{*}{$\mathrm{C}$} & 0.0054 & $* * *$ & 0.0302 & $* *$ & 0.0057 & $* * *$ & 0.0077 & $* * *$ & 0.0018 & & 0.0094 & \\
\hline & $(0.0017)$ & & $(0.0154)$ & & $(0.0017)$ & & $(0.0021)$ & & $(0.0016)$ & & $(0.0201)$ & \\
\hline \multirow[t]{2}{*}{$\mathrm{SFP}(\mathrm{t}-1)$} & 0.9007 & $* * *$ & 0.8606 & $* * *$ & 0.8753 & $* * *$ & 0.8826 & $* * *$ & 0.8323 & $* * *$ & 0.8359 & $* * *$ \\
\hline & $(0.0294)$ & & $(0.0399)$ & & $(0.0304)$ & & $(0.0307)$ & & $(0.0414)$ & & $(0.0338)$ & \\
\hline \multirow[t]{2}{*}{$\mathrm{SCYt}$} & -0.1185 & $* *$ & & & & & & & & & -0.1203 & $* *$ \\
\hline & $(0.0521)$ & & & & & & & & & & $(0.0536)$ & \\
\hline \multirow[t]{2}{*}{ SCOt } & & & -0.0281 & $*$ & & & & & & & -0.0033 & \\
\hline & & & $(0.0164)$ & & & & & & & & $(0.0213)$ & \\
\hline \multirow[t]{2}{*}{ DSPRt } & & & & & -0.0474 & $* *$ & & & & & -0.0434 & $*$ \\
\hline & & & & & $(0.0222)$ & & & & & & $(0.0224)$ & \\
\hline \multirow[t]{2}{*}{ SOIt } & & & & & & & -0.0046 & & & & -0.0126 & $* * *$ \\
\hline & & & & & & & $(0.0033)$ & & & & $(0.0037)$ & \\
\hline \multirow[t]{2}{*}{ STVt } & & & & & & & & & 0.0086 & $* * *$ & 0.0120 & $* * *$ \\
\hline & & & & & & & & & $(0.0029)$ & & $(0.0041)$ & \\
\hline \multirow[t]{2}{*}{ Dt } & -0.0152 & $* * *$ & -0.0150 & $* * *$ & -0.0170 & $* * *$ & -0.0195 & $* * *$ & -0.0159 & $* * *$ & -0.0214 & $* * *$ \\
\hline & $(0.0046)$ & & $(0.0047)$ & & $(0.0047)$ & & $(0.0049)$ & & $(0.0050)$ & & $(0.0044)$ & \\
\hline $\mathrm{R}^{2}$ & 0.9346 & & 0.9334 & & 0.9336 & & 0.9332 & & 0.9344 & & 0.9392 & \\
\hline BG & 1.4810 & & 1.5828 & & 1.2203 & & 1.2977 & & 2.2549 & & 1.2605 & \\
\hline
\end{tabular}

Note: This table reports estimation results for the 3-month futures contract. The dependent variable is the WTI/Brent oil futures price differential (SFP). The explanatory variables are the lagged WTI/Brent oil futures price differential (SFP(t-1)), the WTI/Brent convenience yield spread (SCYt), the WTI/Brent oil consumption spread (SCOt), the WTI/Brent oil production spread in first difference (DSPRt), the WTI/Brent open interest spread (SOIt), the WTI/Brent trading volume spread (STVt), and the dummy variable that takes on value 1 (0) after (before) August 2010 (Dt). Heteroscedasticity robust standard errors are reported in parentheses. For the Breusch-Godfrey Serial Correlation (BG) test, the Wald statistic is reported. Asterisk ***,***) denotes the $10 \%(5 \%, 1 \%)$ level of significance. The sample period runs from January 1993 to December 2016. 


\begin{tabular}{|c|c|c|c|c|c|c|c|c|c|c|c|c|}
\hline Predictors & (1) & & (2) & & (3) & & (4) & & (5) & & (6) & \\
\hline $\mathrm{C}$ & $\begin{array}{c}0.0041 \\
(0.0015)\end{array}$ & $* * *$ & $\begin{array}{c}0.0275 \\
(0.0145)\end{array}$ & $*$ & $\begin{array}{c}0.0042 \\
(0.0015)\end{array}$ & $* * *$ & $\begin{array}{c}0.0047 \\
(0.0017)\end{array}$ & $* * *$ & $\begin{array}{c}0.0036 \\
(0.0017)\end{array}$ & $* *$ & $\begin{array}{c}0.0408 \\
(0.0148)\end{array}$ & $* * *$ \\
\hline $\operatorname{SFP}(t-1)$ & $\begin{array}{c}0.9088 \\
(0.0268)\end{array}$ & $* * *$ & $\begin{array}{c}0.8835 \\
(0.0385)\end{array}$ & $* * *$ & $\begin{array}{c}0.9028 \\
(0.0279)\end{array}$ & $* * *$ & $\begin{array}{c}0.9086 \\
(0.0300)\end{array}$ & $* * *$ & $\begin{array}{c}0.9030 \\
(0.0328)\end{array}$ & $* * *$ & $\begin{array}{c}0.8810 \\
(0.0375)\end{array}$ & $* * *$ \\
\hline $\mathrm{SCYt}$ & $\begin{array}{l}-0.0169 \\
(0.0349)\end{array}$ & & & & & & & & & & $\begin{array}{l}-0.0155 \\
(0.0326)\end{array}$ & \\
\hline SCOt & & & $\begin{array}{l}-0.0264 \\
(0.0153)\end{array}$ & $*$ & & & & & & & $\begin{array}{l}-0.0380 \\
(0.0151)\end{array}$ & $* *$ \\
\hline DSPRt & & & & & $\begin{array}{l}-0.0327 \\
(0.0174)\end{array}$ & $*$ & & & & & $\begin{array}{l}-0.0315 \\
(0.0179)\end{array}$ & $*$ \\
\hline SOIt & & & & & & & $\begin{array}{l}-0.0009 \\
(0.0021)\end{array}$ & & & & $\begin{array}{l}-0.0038 \\
(0.0021)\end{array}$ & $*$ \\
\hline STVt & & & & & & & & & $\begin{array}{c}0.0006 \\
(0.0018)\end{array}$ & & $\begin{array}{c}0.0001 \\
(0.0019)\end{array}$ & \\
\hline Dt & $\begin{array}{l}-0.0123 \\
(0.0043)\end{array}$ & $* * *$ & $\begin{array}{l}-0.0112 \\
(0.0044)\end{array}$ & $* *$ & $\begin{array}{l}-0.0126 \\
(0.0043)\end{array}$ & $* * *$ & $\begin{array}{l}-0.0128 \\
(0.0041)\end{array}$ & $* * *$ & $\begin{array}{l}-0.0122 \\
(0.0043)\end{array}$ & $* * *$ & $\begin{array}{l}-0.0130 \\
(0.0040)\end{array}$ & $* * *$ \\
\hline $\mathrm{R}^{2}$ & 0.9495 & & 0.9501 & & 0.9499 & & 0.9495 & & 0.9495 & & 0.9510 & \\
\hline BG & 1.9908 & & 2.3453 & & 1.8989 & & 1.8549 & & 2.0152 & & 1.8586 & \\
\hline
\end{tabular}

Note: This table reports estimation results for the 6-month futures contract. The dependent variable is the WTI/Brent oil futures price differential (SFP). The explanatory variables are the lagged WTI/Brent oil futures price differential (SFP(t-1)), the WTI/Brent convenience yield spread (SCYt), the WTI/Brent oil consumption spread (SCOt), the WTI/Brent oil production spread in first difference (DSPRt), the WTI/Brent open interest spread (SOIt), the WTI/Brent trading volume spread (STVt), and the dummy variable that takes on value 1 (0) after (before) August 2010 (Dt). Heteroscedasticity robust standard errors are reported in parentheses. For the Breusch-Godfrey Serial Correlation (BG) test, the Wald statistic is reported. Asterisk * (**, ***) denotes the $10 \%(5 \%, 1 \%)$ level of significance. The sample period runs from January 1993 to December 2016. 


\begin{tabular}{|c|c|c|c|}
\hline \multicolumn{4}{|c|}{ Table 7: SUR model estimated results } \\
\hline Predictor & $\begin{array}{l}\text { Coefficient } \\
\text { estimate }\end{array}$ & Significance & $\begin{array}{c}\text { Standard } \\
\text { error }\end{array}$ \\
\hline \multicolumn{4}{|c|}{ 1-Month Futures Contract } \\
\hline $\mathrm{C}$ & 0.0487 & $* *$ & $(0.0191)$ \\
\hline $\mathrm{SFP}(\mathrm{t}-1)$ & 0.7119 & $* * *$ & $(0.0281)$ \\
\hline $\mathrm{SCYt}$ & -0.4877 & $* * *$ & $(0.0400)$ \\
\hline SCOt & -0.0440 & $* *$ & $(0.0210)$ \\
\hline DSPRt & -0.0812 & $* * *$ & $(0.0301)$ \\
\hline SOIt & -0.0013 & & $(0.0033)$ \\
\hline STVt & 0.0096 & $* *$ & $(0.0049)$ \\
\hline Dt & -0.0295 & $* * *$ & $(0.0055)$ \\
\hline $\mathrm{R}^{2}$ & & 0.9117 & \\
\hline \multicolumn{4}{|c|}{ 3-Month Futures Contract } \\
\hline $\mathrm{C}$ & 0.0427 & $* * *$ & $(0.0157)$ \\
\hline $\mathrm{SFP}(\mathrm{t}-1)$ & 0.7640 & $* * *$ & $(0.0236)$ \\
\hline SCYt & -0.2915 & $* * *$ & $(0.0272)$ \\
\hline SCOt & -0.0357 & $* *$ & $(0.0174)$ \\
\hline DSPRt & -0.0535 & $* *$ & $(0.0239)$ \\
\hline SOIt & -0.0024 & $*$ & $(0.0012)$ \\
\hline STVt & 0.0033 & $*$ & $(0.0018)$ \\
\hline Dt & -0.0286 & $* * *$ & $(0.0041)$ \\
\hline $\mathrm{R}^{2}$ & & 0.9274 & \\
\hline \multicolumn{4}{|c|}{ 6-Month Futures Contract } \\
\hline $\mathrm{C}$ & 0.0450 & $* * *$ & $(0.0130)$ \\
\hline $\operatorname{SFP}(\mathrm{t}-1)$ & 0.8128 & $* * *$ & $(0.0222)$ \\
\hline SCYt & -0.2033 & $* * *$ & $(0.0212)$ \\
\hline SCOt & -0.0396 & $* * *$ & $(0.0144)$ \\
\hline
\end{tabular}




\begin{tabular}{cccc} 
DSPRt & -0.0404 & $* *$ & $(0.0203)$ \\
SOIt & -0.0016 & & $(0.0010)$ \\
STVt & 0.0003 & & $(0.0010)$ \\
Dt & -0.0226 & $* * *$ & $(0.0036)$ \\
\hline $\mathrm{R}^{2}$ & & 0.9405 &
\end{tabular}

Note: This table reports estimation results for the Seemingly Unrelated Regression (SUR). The dependent variable is the WTI/Brent oil future price differential (SFP). The explanatory variables are the lagged WTI/Brent oil futures price differential (SFP(t-1)), the WTI/Brent convenience yield spread (SCYt), the WTI/Brent oil consumption spread (SCOt), the WTI/Brent oil production spread in first difference (DSPRt), the WTI/Brent open interest spread (SOIt), the WTI/Brent trading volume spread (STVt), and the dummy variable that takes on value $1(0)$ after (before) August 2010 (Dt). Asterisk * (**,***) denotes the 10\% (5\%, $1 \%$ ) level of significance. The sample period runs from January 1993 to December 2016. 


\begin{tabular}{cccccc}
\hline \multicolumn{7}{l}{ Table 8: SUR model for coefficient differences } & & & \\
\hline & SCY & SCO & DSPR & SOI & STV \\
\hline Chi-sq & 71.1255 & 0.4653 & 3.9663 & 0.4254 & 5.1287 \\
df & 2 & 2 & 2 & 2 & 2 \\
Prob(Chi-sq) & $0.0000^{* * *}$ & 0.7924 & 0.1376 & 0.8084 & $0.0770^{*}$ \\
\hline
\end{tabular}

Note: This table reports the coefficients differences among the determinants of WTI/Brent convenience yield spread (SCY), WTI/Brent oil consumption spread (SCO), WTI/Brent oil production spread in first difference (DSPR) WTI/Brent open interest spread (SOI), and WTI/Brent trading volume spread (STV) under the null hypothesis of no significant difference among the coefficients. This test is measured by the Chi-square goodness-of-fit. Each variable (SCY, SCO, DSPR, SOI and STV) represents the equality of coefficients among the corresponding maturities of 1-month, 3-month, and 6-month contracts. For example, SCY denotes: SCY M1 = SCY M3 = SCY M6. M1 = one-month futures contract, M3 = three-month futures contract, M6 = six-month futures contract. Because we test for a significant difference among three coefficients, we impose two restrictions and therefore the degrees of freedom (df) equal to 2 . The $\mathrm{p}$ value is associated to the Chi-square. Asterisk $*(* *, * *)$ denotes the $10 \%(5 \%, 1 \%)$ significance level. The sample period runs from January 1993 to December 2016. 


\begin{tabular}{|c|c|c|c|}
\hline \multicolumn{4}{|l|}{ Table 9: F test } \\
\hline & $\begin{array}{l}\text { 1-Month Futures } \\
\text { Contract }\end{array}$ & $\begin{array}{l}\text { 3-Month Futures } \\
\text { Contract }\end{array}$ & $\begin{array}{c}\text { 6-Month Futures } \\
\text { Contract }\end{array}$ \\
\hline F-stat & 13.5533 & 4.6238 & 2.4399 \\
\hline Chi-sq & 67.7667 & 23.1193 & 12.1995 \\
\hline $\mathrm{df}$ & 5 & 5 & 5 \\
\hline Prob(F-stat) & $0.0000 * * *$ & $0.0005^{* * *}$ & $0.0347 * *$ \\
\hline $\operatorname{Prob}(\mathrm{Chi}-\mathrm{sq})$ & $0.0000^{* * *}$ & $0.0003 * * *$ & $0.0322 * *$ \\
\hline \multicolumn{4}{|c|}{$\begin{array}{l}\text { Note: This table reports the finite sample F-statistic and the asymptotic Chi-square statistic with associated } \\
\text { p-values regarding the } 1 \text {-month, 3-month and } 6 \text {-month futures contracts under the null hypothesis of } \\
\alpha_{2}=\alpha_{3}=\alpha_{4}=\alpha_{5}=\alpha_{6}=0 \text {. WTI/Brent convenience yield spread }=\alpha_{2}=\mathrm{SCY} \text {. WTI/Brent oil } \\
\text { consumption spread }=\alpha_{3}=\mathrm{SCO} \text {. WTI/Brent oil production spread in first difference }=\alpha_{4}=\mathrm{DSPR} \text {. } \\
\text { WTI/Brent open interest spread }=\alpha_{5}=\mathrm{SOI} \text {. WTI/Brent trading volume spread }=\alpha_{6}=\mathrm{STV} \text {. The degrees of } \\
\text { freedom (df) associated equal to } 5 \text { (number of regressors estimated). Asterisk } *(* * * * *) \text { denotes the } 10 \% \\
(5 \%, 1 \%) \text { significance level. The sample period runs from January } 1993 \text { to December } 2016 \text {. }\end{array}$} \\
\hline
\end{tabular}

